\title{
Abstracts of the ASHS Southern Region 50th Annual Meeting
}

\section{Little Rock, Arkansas}

\section{3-6 February 1990}

\section{Extension}

PUBLICATION OPPORTUNITIES IN HORTTECHNOLOGY

Arlie A. Powell, Department of Horticulture, Auburn

University, Auburn, AL 36849

A journal of the type proposed as HortTechnology is long overdue. Extension and other applied horticulturists thought Hortscience, when introduced several years ago, would become their primary repository for reporting professional accomplishments, etc. However, this 2nd Journal quickly became the house organ for short term research. The format for HortTechnology looks good if implemented as proposed. An overview committee consisting of a majority of Extension Horticulturists should be established to monitor progress and development of this publication (in addition to present development committee). Extension specialists and others involved in applied horticulture must avail themselves of the opportunity to publish in one or more of the peer reviewed as well as other sections of the publication. To make this journal a success Extension workers must support this effort through submitting papers on a regular basis. This referred journal could and probably will become the most popular and widely used of ASHS publications.

\section{Floriculture and Ornamentals}

LANDSCAPE AND TURFGRASS FIELD DAYS AT NORTH CAROLINA STATH UNIVERSITY

M. A. Powell, Department of Horticulture, North Carolina State University, Raleigh, NC 27695-7609

A very successful project at $N$. C. State University began in 1983, with the first N. C. Landscape and Turfgrass Field Day. The Field Day is co-sponsored with the N, C. Landscape Eontractors Association and the Turfgrass Council of North Carolina. The Field Day is an excellent opportunity for industry to visit with faculty and observe research projects and extension demonstrations. Over the years the attendance has grown to over 1200 paid attendees. The Field Day is actually divided into four separate functions: 1) Educational Field Day, 2) Product and Equipment Field Day, 3) Turf Workshops, and 4) Construction Workshops. The Extension and Research projects benefit financially from this endeavor. Any projects from the Field Day are given back to the University. This typically is about $\$ 4000.00$. The Field Day is held the third Wednesday in May, rain or shine.

OBSERVATIONS OF INTERVEINAL CHLOROSIS ON MALUS SARGENTII T. Scott Starr* and L. F. Thompson, Department of Agronomy, University of Arkansas, Fayetteville, AR 72701

Interveinal chlorosis has been observed on the oldest leaves of several varieties of flowering crabapple (Malus sargentii Reh1). Our objective was to identify the cause of this disorder. Foliage and soil from 20 Sargent crabapple trees growing on 12 different sites were analyzed for possible nutrient deficiencies or excesses. Analyses showed $\mathrm{N}$ to be slightly low, Ca high, and $\mathrm{Mg}$ low in all leaf samples. Soil analysis showed $\mathrm{Ca}$ to be abnormally high at all sites. We concluded that the leaf discoloration was caused by a $\mathrm{Mg}$ deficiency due to $\mathrm{Ca}$ suppression of the $\mathrm{Mg}$ and that the low foliar $\mathrm{N}$ might be a contributing factor in the interveinal chlorosis.

EXAMINATION OF JUVENILITY IN GAILLARDIA PULCHELLA

Kathleen $M$. Bourke and Robert $E$ Iyons, Department of Horticulture, Virginia Polytechnic Institute and state University, Blacksburg, VA 24061

Gaillardia pulchella is an annual wildflower with ornamental potential native to the South and Southern West part of the $U$. S. This experiment attempted to further describe the long day (LD) flowering requirement, approximate the length of the juvenility phase, and characterize apical events during floral initiation. Plants were transferred from short day to LD at various leaf numbers and the time to first flower was recorded from the onset of LD. A quadratic response described the data and indicated that a minimum of 19-20 expanded leaves were needed to flower most rapidly (49 days) once placed in LD. Histological results characterizing apical events will also be discussed.

THE STEPHEN F. AUSTIN STATE UNIVERSITY ARBORETUM: DEVELOPING AN EDUCATIONAL OUTREACH POTENTIAL

R. Rankin* and D. L. Creech, Department of Agriculture, Stephen F. Alstin State University, Nacogdoches, TX 75962 Horticultural enrollments have fallen since the late 1970 's and faculties are scrambling to find new ways to creatively finance educational and outreach programs. The Stephen F. Austin State University Arboretum was sanctioned by the administration in March, 1987. Eight acres of land that lie on LaNana creek are directly associated with the Agriculture building and horticultural facility. Gardens that feature a wide range of rare, unusual, and untested landscape plants are being developed by students, volunteers, and a mix of outside monies. 'The history of a City/SFASU project to develop a three mile LaNana Creek trail will be described. A cooperative effort with the Herb Society of Deep East Texas, a 121-acre cunservancy easement project, and Asian vegetable studies are currently under the arboretum umbrella.

EVALUATIONS OF PRODIAMINE AND METHAZOLE FOK CONTAINER ORNAMENTAL WEED CONTROI

D. W. Wells, R. J. Constant in*, and J. W. Wells, Hammond Research Station, Louisiana Agricultural Experiment SLation, L.S.U. Agricultural Center, Hammond, LA 70403

Six prodiamine treatments, three applied alone and three applied in combination with methazole, were compared with oxyf luorf en/oryzalin, oxadiazon, and controls (weeded and non-weeded) on ornamental and weed species. Omamentals included green liriope, Astatic fasmine, serissa, gardenia, 'Needlepoint' holly, Japanese yew, 'Prostrata' juniper, and 'Carror' azalea. Weeds grown in separate containers were goosegrass, crabgrass, pigweed, and prostrate spurge. At 13 days after treatment (DAT), oxadlazon and oxyfluorfen/ oryzalin caused some contact burn on lirtope, and the injury persisted until the 81 DAT rating. Methazole/prodiamine treatments caused chlorosis on gardenia leaf tips, with plants recovering by 61 DAT. These combinations also resulted in slight injury to azalea at the first rating, but the injury disappeared by the second rating. Control of goosegrass, crabgrass, and pigweed was good to excellent with all chemical treatments. Control of spurge using oxadiazon and oxyfluorfen/oryzalin decreased at 81 and 100 DAT. 
EFFECTS OF SPECTRAI FILTERS ON GROWTH OF ROSA $X$ HYBRIDA AND EXACUM AFEINE. Margaret J MCMahon ano Joha W. Kelly, Department of Horticulture, Clemson University, Clemson, SC 29634-0375.

The growth of Rosa hybrida and Exacum affine under different spectral filters was evaluated. Three filters that altered light quality were developed. One, a red textile dye, filtered out much of the blue/green portion of the light spectrum but did not change far-red to red (FR/R) light ratio. Another, a blue textile dye, raised $F R / R$ by filtering out a portion of red light. The third, a salt (copper sulfate) lowered FR/R by filtering out a greater portion of far-red than red light. 'Two controls were used that did not alter light quality. The filters were installed in specally built growth chambers. Photosyrthetic Photon Flux Density (PPFD) was acljusted to equal values in each chamber.

Plants of both species were significantly shorter and had higher leaf chlorophyll, when grown under the low $F R / R$ filter.

USE OF GEOTHXIILE DISCS AS CHEMICAL CARRIHRS FOR CONIATNER NURSERY STOCK PRODUCTION

Bonnie Appleton and Jeffrey Derr, Harmton Roads Agricultural Experiment Station, Virginia Polytechnic Institute and State University, Virginia Beach, VA 23455 Discs of several materials, including paper,

fiberglass, black polyethylene and several woven and nonwoven (spunbonded) polypropylene geotextiles or landscape fabrics, were tested for container weed control. Weed growth developed with some materials due to decomposition and lack of proper fit.

one commercially available combination geotextileherbicide product gave excellent weed control. A slowrelease fertilizer was then attached, giving not only excellent weed control but also promoting satisfactory nursery plant growth. This concept of using a geotextile disc as a chemical carrier (a "horticultural collar") is being further developed.

EFFECTS OF IRRIGATION FREQUENCY ON PLANT GROWTH AND NUTRIENT LEVELS OF PINE BARK MEDIA T. E. Bilderback, Department of Horticultural Science, North Carolina State University, Raleigh, NC 27695-7609

llex $\mathrm{x}$ 'Nellie $\mathrm{R}$. Stevens' holly, Rhododendron sp. 'Hinodegeri' azalea and Pyracantha coccinea, scarlet firethorn rooted cuttings were potted in. 3.81 containers. Irrigation was applied by Dram rings daily, or every 2,4, or 6 days. Approximately $1000 \mathrm{ml}$ of water were applied at each irrigation. Three container media, including pine bark, and pine bark amended with either TerraSorb AG synthetic moisture extender incorporated at $1.2 \mathrm{~kg} / \mathrm{m}^{3}$ or Aqua-Gro $G$ wetting agent incorporated at $0.9 \mathrm{~kg} / \mathrm{m}^{3}$ plus monthly drenches of $700 \mathrm{ml}$ of $2500 \mathrm{ppm}$ Aqua-Gro L were compared for physical and chemical properties and plant growth responses. Decreasing irrigation decreased $\mathrm{pH}$, increased nutrient leachate levels, and increaséd foliar tissue levels of $\mathrm{N}, \mathrm{P}, \mathrm{K}, \mathrm{Ca}$,and $\mathrm{Fe}$ in holly and azalea. Pyracantha top and root dry weight was reduced at 4 and 6 day irrigation intervals, holly top growth was reduced by 6 day and azalea had greatest shoot growth at 2 day irrigation and was reduced by other irrigation frequencies. Top growth of all 3 species and root growth of pyracantha was reduced in the pine bark treatment.

ROW MANAGEMENT OF FIELD-GROWN NURSERY STOCK

L.P. Baldridge and S.E. Newman*, Department of Horticulture, Mississippi State University, Mississippi State, MS 39762

Most field production of woody ornamental plants involves clean cultivation of rows, performed by either mechanical or chemical means. Grass cover has been shown to reduce erosion, but may have a detrimental effect on the growth and vigor of young trees. Clover cover has been shown to not adversely affect plant growth. The objective of this study was to compare the relative merits of three row covers, clean cultivated, pine bark mulch and kobe lespedeza clover, in combination with two irrigation rates, low and high, on field-grown red bud and crape myrtle plants.

Crape myrtle and red bud plants were tallest and had a larger caliper when grown with a clean row or with pine bark mulch. Kobe lespedeza clover reduced plant growth of both species when supplemental irrigation was not provided. Clover reduced plant height and caliper of red bud even when irrigated. Generally, plants grown under pine bark mulch were more efficient in water use as shown by greater stomatal conductance in August.

RELATIONSHIPS OF IRRIGATION AND MEDIUM COMPOSITION TO TEMPERATURE DYNAMICS IN CONTAINER MEDIA

Chris A. Martin and Dewayne L. Ingram*, Department of Environmental Horticulture, University of Florida, Gainesville, FL 32611

Thermal properties of pine bark : sand container media as a function of volumetric water content and effectiveness of irrigation as a tool for modulating high temperatures in container media were studied. Volumetric water and sand content interacted to affect container medium thermal diffusivity. Adding sand to a pine bark container medium decreased thermal diffusivity if volumetric water content was less than 10 percent and increased thermal diffusivity if volumetric water content was between 10 and 70 percent. Thermal diffusivity was greatest for a 3 pine bark : 2 sand container medium if volumetric water content was between 30 and 70 percent. Irrigation was used to decrease temperatures in 10-liter container media. Irrigation water at $26^{\circ} \mathrm{C}$ was more effective if 1) volumes equaled or exceeded $3000 \mathrm{ml}, 2$ ) applications were made during mid-day, and 3) sand was present in the container medium compared to pine bark alone. However, due to the volume of water required to lower container media temperatures, nursery operators should first consider reducing incoming irradiance via overhead shade or container spacing.

QUALITY STANDARDS FOR CHRISTMAS TREES: HARMFUL OR HELPFUL?

Orville M. Lindstrom* and Wojciech J. Florkowski, Department of Horticulture and Agricultural Economics, respectively, The University of Georgia, Georgia Station, Griffin. GA 30223

It is more important than ever to produce a quality Christmas tree because of increasing competition in the Christmas tree market. Grade standards are intended to reflect quality, as defined by the consumer, to the grower. The USDA revised a set of voluntary standards for Christmas trees effective October 30, 1989. The existence of different grade standards cause the existence of several prices that correspond to each grade. The price differentials among grades should reflect the quality or desired consumer attribute. Therefore, a description of a grade that is not reflective of that desired by the consumer can lead to missallocation of resources by producers resulting in economic losses. The new USDA standards did not include consumer opinion information into the new standards, therefore, we feel these standards are more applicable to producer-wholesale transactions, and not that of the producerconsumer. It was found that over $75 \%$ of surveyed growers in Georgia sold almost $80 \%$ of their trees as choose and cut, not wholesale. Consumer demand will drive the Christmas tree market and, therefore, consumer preferences need to be incorporated into the grade standards.

\section{PRELIMINARY STUDIES ON COLD HARDINESS OF SOUTHERN MAGNOLIA}

Orville M. Lindstrom* and Glen W. Kent, Department of Horticulture, The University of Georgia, Georgia Station, Griffin, GA 30223 Magnolia has graced southern landscapes for many years. However, its northern distribution is limited due to injury at low, freezing temperatures. Laboratory methods are available to assess the cold hardiness of many plants, but specific methods for Southern magnolia have not been established. Effects of exposure time, temperature at which plants were frozen, rate of warming, sample size and methods of injury evaluation were investigated. With exposure to -1.5 and $-4 \mathrm{C}$ the leaves and stems were not injured when frozen for up to $7 \mathrm{~h}$. Stems and leaves that were nucleated with ice at $-4 \mathrm{C}$ underestimated the cold hardiness as compared to similar plants that were nucleated at -1.5 and $-3 \mathrm{C}$. Samples warmed as taken from the temperature bath at $4 \mathrm{C}$ or at $4 \mathrm{C} / \mathrm{hr}$ in the bath exhibited less injury than those taken directly out of the bath and exposed to room temperature. Similar cold hardiness determinations were obtained using whole and half leaf samples, while a quarter of a leaf or a leaf disk exhibited high variability and resulted in unreliable cold hardiness determinations. Visual analysis for injury was compared to electrolyte leakage and similar cold hardiness levels were obtained using the two methods. 
IN VITRO AND MACROPROPAGATION OF DYSSODIA PENTACHETA

Thomas W. Zimmerman*, Fredrick T. Davies and Jayne M. Zajicek Department of Horticultural Sciences, Texas A\&M University, College Station, TX 77843-2133

Dyssodia pentacheta, a low growing perennial Texas wild flower with potential for use in low maitenance landscapes, was propagated in vitro and with cuttings under a mist system. Over $80 \%$ of both semihardwood terminal cutting from stock plants and in vitro grown nodal segments, dipped in $0,3,10$, or $30 \mathrm{M}^{-3} \mathrm{IBA}$, formed roots after 4 weeks under an intermittent mist system. A $300 \mathrm{M}^{-3}$ IBA basal dip was lethal to the cuttings. Dyssodia produced significantly more shoots per nodal explant in vitro on semisolid $(2 \mathrm{~g}$ $1^{-1}$ Gelrite) WPM with $1-10 \mathrm{M}^{-6} \mathrm{BA}$ than combinations of BA and $0.5 \mathrm{M}^{-6} \mathrm{NAA}$. Shoots were successfully subcultured and grown for two passes on semisolid growth regulator free medium. When maintaining Dyssodia in vitro on WPM, void of plant growth regulators, $1 \%$ sucrose promoted shoot growth and suppressed phenolic production better than $2 \%$ sucrose.

BRANCHING AND VEGETATIVE GROWTH MODIFICATION OF PHOTINIA $X$ FRASERI WITH EXOGENOUS PLANT GROWTH REGULATORS Alien D. Owing $S^{*}$ and Steven $E$. Newman. Department of Horticulture, Mississippi State University, Mississippi State, MS 39762 .

Four rates of seven plant growth regulators were foliar-applied to 11.4 liter. containers of Photinia $x$ fraseri after initial root establishment. Growth regulators studied were uniconazole, paclobutrazol, dikegulac-sodium, ancymido1, 6-BA, $\mathrm{GA}_{4+7}$ and, 6-BA + $\mathrm{GA}_{4+7}$. Six months after application, plant height, plant width, growth index, and number of lateral and terminal branches were recorded.

Applications of uniconazole (30 mg a.i./1iter), 6$\mathrm{BA}$ alone or in combination with $\mathrm{GA}_{4+7}$, and" dikegulacsodium stimulated lateral branching. The number of lateral branches increased linearly as paclobutrazol rates increased from 60 to $180 \mathrm{mg}$ a.i./liter. Growth index decreased with increasing application rates of uniconazole and paclobutrazol, while the growth index of photinia treated with other growth regulators wasn't affected by application rate. Plant height was increased in $\mathrm{GA}_{4+7}$ trcated plants.

\section{EFFECT OF GROWTH REGULATORS ON TWO PYRACANTHA COCCINEA CULTIVARS}

Janet $C$. Henderson* and Thomas $H$. Nichols, Department of Horticulture and Landscape Architecture, Oklahoma State University, Stillwater, OK 74078

Pyracantha coccinea 'Lalandei' and 'Kasan' were treated with a foliar application of 25,50 or $100 \mathrm{mg} / \mathrm{l}$ uniconazole, 3000 $\mathrm{mg} / \mathrm{l}$ chlormequat, a soil drench of $0.25,0.50$ or 1.00 $\mathrm{mg} /$ container of uniconazole, or $30 \mathrm{mg} /$ container chlormequat. Heights of plants receiving foliar applications of uniconazole were significantly lower than untreated plants in both cultivars. Uniconazole soil drenches also reduced plant height in both cultivars, but differences were not apparent until 8 weeks after treatment. Chlormequat treatments had little effect on plant growth. At harvest, stem dry weight was significantly lower in both cultivars with uniconazole soil drenches and in 'Lalandei' treated with 50 and $100 \mathrm{mg} / \mathrm{l}$ and in 'Kasan' treated with 100 $\mathrm{mg} / \mathrm{l}$ as a foliar application. There was also a tendency for leaf area to increase with uniconazole foliar applications.

CONTROL OF BASAL SUCKER GROWTH ON TREE-FORM CRAPE MYRTLE IN THE LANDSCAPE WITH NAA. H. Brent Pemberton* and Kent E. Cushman, Texas A\&M University Agricultural Research and Extension Center, P. O. Drawer E, Overton, Texas 75684

Basal sucker shoots between 15 and $30 \mathrm{~cm}$ tall on multi-branched, tree-form crape myrtles (Lagerstroemia indica) were sprayed to run-off with NAA solutions of $0,0.5,1.0$, and $1.5 \%$ in June. Flve weeks later, sucker growth was assigned a visual rating from 0 to 4 denoting 0 to $100 \%$ control. Heights of three basal shoots were measured for each plant as another indicator of control. Visual ratings increased linearly from 1 to 3.6 as NAA increased from 0 to $1.5 \%$. Basal shoot height decreased quadratically with increasing NAA concentration with the 1.0 and $1.5 \%$ NAA treatments resulting in a $53 \%$ reduction when compared to the control. Further work is needed to assess the effect of NAA on flowering and to detcrmine if spring applications will result in scason long control.

GROWTH AND FLOWERING OF MANDEYILLA 'ALICE DU PONT' IN RESPONSE TO UNICONAZOLE. Gary J. Keever* and C. Fred Deneke, Department of Horticulture and ATabama Agricultural Experiment Station, Auburn University, AL 36849.

Vegetative growth and flowering of Maridevilla 'Alice du Pont' in response to foliar-applied uniconazole were determined in 3 experiments. Plants pruned to 2 nodes were treated with foliar applications of 30 , 60,90 , and $120 \mathrm{ppm}$ uniconazole. A11 uniconazole rates induced temporary leaf cupping and suppressed growth excessively for at least 6 weeks; thereafter, plants grew similarly to the control. Single applications of $5,10,15$, and $20 \mathrm{ppm}$ uniconazole were not effective in controlling vegetative growth, but multiple applications of $5.0,7.5,10.0,12.5,15.0,17.5$, and $20.0 \mathrm{ppm}$ uniconazole provided acceptable, but not excessive, suppression of internode elongation. As the concentration of uniconazole increased, the interval between applications increased. flowering was delayed and bloom size was reduced as uniconazole rate increased.

GROWTH AND FLOWERING OF GARDEN IRISES UNDER GREEMHOUSE FORCING

Leah Chaudoir* and A.E. Einert, Department of Horticultuice and Forestry, University of Arkansas, Fayetteville, AR 12701

Rhizomes of Iris germanica L. 'Pretty Please' were stored either dry at $21^{\circ} \mathrm{C}$ or potted at $10^{\circ} \mathrm{C}$ for $0,4,9$, $11,13,15$, or 17 weeks. After storage, dry rhizomes were potted and placed in a forcing greenhouse. Potted rhizones were removed from the $10^{\circ} \mathrm{C}$ cooler and placed in the same greenhouse. Both were forced under longdays $(16 \mathrm{hr})$. A control group with no rhizome storage received natural daylength. Plants flowered without rhizome storage if grown under longdays. Four wcoks of rhizome storage (cool or warm) significantly hastened flowering of potted irises over those receiving no rhizome storage, as well as producing the highest percentage of flowering plants. Potted rhizomes chilled for 17 weeks had the shortest forcing period, but only 50\% of plants flowered. Plants receiving natural daylength did not flower. Greenhouse forced plants did not produce more than three flowers per scape. Foliage height at flowering decreased significantly after 15 weeks of cool rhizome storage.

MOLYBDENUM SOURCES FOR POINSETTIAS

Kenneth C. Sanderson, Alabama Agricultural Experiment Station Auburn University, Alabama 36849-5408

'Annette Hegg Brilliant Diamond' poinsettias were directly rooted and grown in 1 sphagnum peat moss: 1 perlite medlum treated with six treatments of Mo and a check. The treatments were: 1) $0.2 \mathrm{ppm}$ Mo liquid weekly, 2) $3.0 \mathrm{mg}$ Mo plaster-of-Paris tablet, 3) $0.6 \mathrm{~g}$ per liter liquid STEM once, 4) $0,6 \mathrm{~kg}$ per m Micromax incorporated (greplant), 5) $3.3 \mathrm{~kg}$ per $\mathrm{m}^{3}$ Perk incorporated, 6) $3.0 \mathrm{~kg}$ per $\mathrm{m}^{3}$ Esmigran incorporated, 7) $1.2 \mathrm{~kg}$ per $\mathrm{m}^{3}$ FTE 503 , and 8 ) check (untreated). Plant height and foliar Mo, N, and Mn were affected by Mo treatments. Untreated plants were shorter than plants receiving Mo treatments. Weekly liquid Mo treatments $(10.0 \mathrm{ppm})$ yielded plants with the highest foliar Mo content and differed from a11 other treatments. FTE 503 plants ( 4.2 ppm Mo) differ from other Mo treatments and check plants ( $1.4 \mathrm{ppm}$ Mo) Liquid Mo plants $(6.1 \% \mathrm{~N})$ had the highest $\mathrm{N}$ content and differed from all treatments except Perk $(5.8 \% \mathrm{~N})$ and Micromax $(5.8 \% \mathrm{~N})$ and Micromax $(5.8 \% \mathrm{~N})$. plants. Perk-treated plants (155 ppm $\mathrm{Mn}$ ) contained more $\mathrm{Mn}$ than other plants, whereas check plants ( $48.4 \mathrm{ppm} \mathrm{Mn}$ ) and Mo tablet plants (38.4 ppm Mn) contalned the least Mn content. Bract number, plant spread and $\mathrm{Fe}$ content were unaffected by Mo treatments. 
POTASSIUM RATE AND MOTSTURE STRESS: CHANGES IN LEAT WATER RELATIONS OF 'BQNFIRE' SALVIA D. Joseph Eakes $*$, Robert D. Wright ${ }^{2}$ and John R. Seiler ${ }^{2}$,

${ }^{1}$ Department of Horticulture, Auburn University, Auburn University, Alabama 36849; Departments of Horticulture and Forestry, Virginia Polytechnic Institute and State University, Blacksburg, Virginia 24061

Leaf water relations and gravimetric water loss as influenced by $K$ rate $(25,75,150,300,450$ and $600 \mathrm{ppm}$ ) and molsture stress conditioning (MSC - exposing plants to 4 sublethal dry down cycles) were determined for salvia (Salvia splendens 'Bonfire'). K rate and MSC had a synergistic effect on leaf osmotic potentials. Osmotic potentials at both full and zero turgor decreased with increasing $K$ rate and MSC. Differences between MSC and no-MSC plant osmotic potentials increascd as $\mathrm{K}$ rate increascd. Active osmotic adjustment with increasing $K$ rate and MSC resulted in increased cellular turgor potentials. Both high $\mathrm{K}$ rates and MSC reduced plant gravimetric water loss on a unit leaf area basis.

QUALITY AND YIELD OF' AGERATUM, ASTER, CELOSIA AND GODETIA GROWN AS FIELD GROWN CUTFLOWERS

Liliek Utami, Robert G. Anderson*, Robert L. Geneve and Sharon Kester Department of Horticulture and Landscape Architecture, University of Kentucky, Lexington KY 40546

Warm season annual flowers were trialed as field grown cutflowers in the summer of 1989. Plants were transplanted to the field in early or late May and grown at densities of 40 plants $\mathrm{m}^{-2}$ in beds with black plastic mulch, trickle irrigation and support wires. Tall ageratum, 'Horizon Blue', plants were harvested throughout the summer with total yields of 290 stems $\mathrm{m}^{-2}$ with stem lengths over $36 \mathrm{~cm}$ long. Stem lengths increased significantly over the summer; $40 \%$ of the stems harvested in September were over $56 \mathrm{~cm}$ long. Spray asters, 'Matsumoto Blue', Matsumoto Red' and 'Serene Red', were harvested eight weeks afte transplanting with yields of 20 to 30 stems $\mathrm{m}^{-2} ; 60 \%$ of the stems were $36.45 \mathrm{~cm}$ long and $40 \%$ were $46-55 \mathrm{~cm}$ long. Tall, crested celosia, 'Red Chief', 'Gold Chief' and 'Fire Chilef', plants were harvested 8 weeks atter transplanting with yields of 45 stems $\mathrm{m}^{-2}$; over $60 \%$ of the stems were $45 \mathrm{~cm}$ long or tonger. Godetia, 'Grace Red' and 'Grace Salmon', plants sown March 3 and planted in the field April 10. performed well; later plantings were much less successful. Plants were planted at a density of $5 \mathrm{~m}^{-2}$ and produced 25 to 50 flower stems per plant; stem lengths were 30 to $38 \mathrm{~cm}$ long.

BROILER LITTER: POTENTIAL SOIL AMENDMENT FOR BEDDING PLANTS Charles Gilliam* and James Donald, Department of Horticulture I01 Funchess Hall, Auburn University, Alabama 36849-5408 Broiler litter is an abuhdant natural resource in the Southeastern United States. In Alabama, an estimated 1.4 tons are produced annually. * In Expt. 1, two broiler 1itter treatments were compared at 3 rates. Sixty days after planting, growth of 4 bedding plants (Ageratum, begonia, dianthus, and marigold) was greater with both litter treatments at 20 ton/acre rate compared to the standard ferti$11 z$ er recommendation of $1201 \mathrm{bN} / \mathrm{A}$ (applied as $12 \mathrm{~N}-2.6 \mathrm{P}-4.9 \mathrm{~K}$ ). Composting reduced the unpleasant odor associated with traditional deepstack handling of broiler litter. In Expt. 2, selected ratios of broiler litter, pinebark, and cotton waste were mixed and composted. Maximum plant response occurred with a combination of composted media plus commercial fertilizer.

ACCUMULATION OF SOLUBLE SALTS AS AFFECTED BY EBB AND FLOOD SUBIRRIGATION

Mario Perches* \& Don Wilkerson, Department of Horticultural Sciences, Texas A\&M University, College Station, TX 778432134

Ebb and.Flood systems provide an efficient means of subirrigating greenhouse crops. However, substrate accumulation of soluble salts can limit plant growth.

Two treatment irrigation regimes, consisting of $1.70 \mathrm{EC}$ and $0.86 \mathrm{EC}$, were applied to $7.0 \mathrm{~cm}$ pots filled with a standard peat:perlite growing medium. Treatment solutions were changed weekly. Al1 containers were irrigated daily and substrate EC Tevels measured weekly in the upper, middle, and lower $2.33 \mathrm{cms}$ of the container.

Following 6 weeks of observation, mean EC substrate levels ranged from 1.23 mmos/cm to $4.42 \mathrm{mmhos} / \mathrm{cm}$. Significant differences occurred between the upper and middle/bottom portions of the container. There was also a significant interaction between treatment irrigation regimes, substrate layer and week.

In both treatment regimes, salt accumulations in the middle and bottom layers of substrate were within acceptable levels for plant production. NATURE OF HYDROPHILIC POLYMERS AND THEIR EFFECT ON SOIL
PROPERTIES

Yin-Tung Wang*, Texas A\&M University Agricultural Research and Extension Center, 2415 East Highway 83, Wes 7aco, TX 78596

The rate of full hydration for several hydrophil ic polymers differed greatly (starch-based polymers > propenoate-propenamide copolymer $>$ polyacrylamide). Maximum water retention in distilled water varied from over $500 \mathrm{~g}$ to $57 \mathrm{~g}$ of water per $\mathrm{g}$ of different dry materials. All polymers retained less water in the presence of metal ions or fertilizers, with substances releasing $\mathrm{Fe}^{+2}$ being the most detrimental. Potting media containing a polyacrylamide polymer reached maximum water retention after 6 irrigations, while those with Micromax ( a micronutrient source) required 10 irrigat ions to reach maximum hydration. The water-holding capacities of the media declined after repeațed fertilization. Medium bulk density, total water retention, and water retention per unit volume of medium were increased by the incorporation of the polymer, regardless of the presence of Micromax. Non-capillary porosity in medium amended with Micromax progressively decreased as the amount of the polymer increased, but remained unchanged in medium without Micromax. Repeated wet-dry cycles resulted in decreased water retention and increased non-capillary pore space of the media.

FERTILIZER RATE TERMINOLOGY FOR FIELD-GROWN ORNAMENTAL PLANTS: ARE WE CONFUSING OURSELVES?

Thomas Yeager*, Ed Gilman, Gamil Kabbabc, and Jerry Kidder, Departments of Environmental Horticulture and Soil Science, IFAS, University of Florida, Gainesville, FL 32611

Nitrogen fertilizer rates are often expressed as Ib N/A. However, without explanation of the actual area fertilized, exact rates cannot be duplicated because the rate may be given in terms of an acre equivalent. For example, $100 \mathrm{lb} \mathrm{N} / \mathrm{A}$ for turf implies that $100 \mathrm{lb}$ of $\mathrm{N}$ was applied on $43,560 \mathrm{sq} \mathrm{ft}$ or real estate acre (R.E.A.). The same rate applied to row crops where the actual area fertilized consists of bands that total 0.05 of a R.E.A., means that 20 times the amount of fertilizer was applied per sq ft even though the rate was reported as $100 \mathrm{lb}$ of N/A and $100 \mathrm{lb}$ of $\mathrm{N}$ were actually applied. Fertilization of trees in a field nursery is similar in concept, but what does a rate of $100 \mathrm{lb}$ of N/A mean? If the area fertilized around the trees was 0.05 of a R.E.A., it is not clear whether $0.002 \mathrm{lb} \mathrm{N} / \mathrm{sq} \mathrm{ft}$ or $0.04 \mathrm{lb} \mathrm{N} / \mathrm{sq} \mathrm{ft}$ was applied. If $0.002 \mathrm{lb} \mathrm{N} / \mathrm{sq}$ $\mathrm{ft}$ was applied, then $5 \mathrm{lb}$ of $\mathrm{N}$ would have been applied on 0.05 of a R.E.A., thus the rate was given as $100 \mathrm{lb}$ N/A equivalent. To avoid confusion, area fertilized per plant or tree, amount per unit area, number of appllcations per year and number of plants per R.E.A. are needed to actually calculate the amount of $\mathrm{N}$ applied per year per R.E.A.

\section{Fruit}

COLD HARDINFSS OF TWELVE SEFDIING POPUIATTONS OF BLACKBERRTES Timothy F. Bourne and James N. Moore, University of Arkansas, Fayetteville, Arkansas 72701 .

Cold hardiness was evaluated in twelve seedling populations of tetraploid blackberry, in 1988 and 1989. Seedling populations resulted from crosses made between nine parents of three different categories of cold hardiness. Viability testing of xylem, phloem, and bud tissues were conducted following expnsure of tissues to a low temperature estimated to kill one-half of all tissues. Tissues were rated as alive if green and dead if any browning of tissue was seen.

Significant population effects (Pr.05) were seen for xylem and bud survival in 1988 and for xylem, phloem, and bud survival in 1989. Results were similar for the two years, although there was a greater discrimination between populations for xylem and phloem survival in the second year. The four populations having 'Darrow' as a parent consistently showed greater survival than the other eight lines. The six populations which had 'Brison' as one parent showed consistently poor survival with the exception of one resulting from a cross of 'Brison' $x$ 'Darrow'. This population showed consistently good hardiness, indicating that dominance effects may play a role in cold hardiness of blackberries. 
One-Sided Shift Trel1ising Addresses Harvest, Pest Management and Culturat Problems in Rubus - Herbert D. Stiles, VPI\&SU, Southern Piedmont Agricultural Experiment Station, Blackstone, VA 23824

Static- $V$ trellis increases raspberry yield, but fruiting shoots grow toward its center making harvest difficu?t. Shading causes early leaf abscission and it favors fungus diseases inside the $v$. Static training of floricanes and - primocanes to opposite sides of a $V$ trellis prevents neither harvest difficulty, nor primocane injury during harvest. In 1988-89 harvest difficulties were reduced by bloomtime shifting of floricanes on a V-trellis. Over $90 \%$ of fruiting shoots were oriented to the trellis' exterior, but primocane shading and early leaf abscission continued. The 'bent fence' trellis was designed and tested in 1989. It shifts floricanes from horizontal orientation to an upright position on one side of a $V$-shaped trellis, thus retaining outward display of fruiting shoots and achieving unobstructed display of primocanes on the opposite side. Harvest efficiency, disease reduction, accurate deposilion of pesticides, avoidance of solar injury (sun scald), and adaptation of mechanical pest control procedures are potentiated by this system. It al so reduces impediments to studies of carbohydrate partitioning, photosynthetic efficiency, yield efficiency, and intraplant competition.

EVALUATION OF LIVING MULCH SYSTEMS FOR RABBITEYE BLUEBERRY PRODUCTION

Kim Patten*. Gary Nimr and Elizabeth Neuendorff, Texas Agricultural Experiment Station, Overton, Texas 75684

Blueberry production is enhanced by the use of an organic mulch An alternative to off-farm sources of mulch is the production of winter and summer living mulch cover crops grown in the row middles of the blueberry planting. These crops are mowed and then windrowed for use as a mulch. We evaluated living mulch crops for blueberries for the following parameters: adaptation to low soil $\mathrm{pH}$, mulch production, ease and cost of stand establishment, mowing tolerance, allelopathic weed control, and $\mathrm{N}$ contributed by mulch. Rye, ryegrass, and crimson clover were the most overall suitable crops for the winter, while for summer, pearl millet was best adapted. Nitrogen was- the major limiting factor that affected nonlegume production. Legume yields were limited by deer foraging and low soil $\mathrm{pH}$. Pearl millet had the greatest allelopathic response on weeds of all cover crops tested. Maximum dry matter production for the living mulches ranged from $6000 \mathrm{~kg} / \mathrm{ha}$ for elbon rye in the winter, to $30,000 \mathrm{~kg} / \mathrm{ha}$ for pearl millet in the summer. With the appropriate cover crop selection and adequate soil fertility living mulches appear to be a efficacious practice to aid blueberry production in the south.

INLUENCE OF MULCH AND IN-GROUND AMENDMENTS ON ROOT WEIGHT AND DISTR I BUT ION OF RABBITEYE BLUEBERR IES. D.L. Creech*, C. Martindale, and R. Rankin, Untversity, Nacogdoches, TX 75962

Brightwell and Climax plants were established in March, 1987, under the following above-ground treatments: 1) polyfabric weed barrier, 2) a $6 \mathrm{~cm}$ deep, 1-meter wide strip of continuous bark, and 3) zero. Below-ground treatments included, i) 19 liters peatmoss, 2) 19 liters pine bark, 3) a continuous bark strip, tilled in, and 4) zero. A randomized complete block design was utilized with above-ground treatments as main plots and in-ground. treatments as split plots. After three years, plants under polyfabric had higher above-ground dry weights, growth indexes, plant height, root dry weights and root lengths than plants under continuous bark or zero. In the deep, coarse, easily-leached sand, all roots were very shallow $(0-20 \mathrm{cms})$ and concentrated along the drip line and in organic matter fractions. There were no significant differences between in-ground treatments.

RESPOISE OF SOUTHERN HIGHBUSH BLUEBERRY TO SAWDUST MULCH John R. Clark* and James N. Moore, Department of Iorticulture -and Forestry, University of Arkansas, Fayetteville, AR 72701

The southern highbush blueberry cultivars 'Blueridge', 'Cape Fear', 'Georgiagem' and '0'Neal' were evaluated for their response to sawdust/woodchip mulch for five years at Clarksville, Arkansas on a Linker fine sandy loam soil. lulched plants produced higher yields and larger plant volumes than non-mulched. Berry weight was similar for mulch treatment except for the first frulting year. All cultivars responded to mulch, although 'Blueridge' and 'Cape Fear' produced the higher yields. General response of these cultivars of southern highbush was similar to that of northern highbush in previous mulch studies in Arkansas.

EFFECT OF NITROGEN, POTASSIUM AND MAGNESIUM ON YIELD, PRUNING WEIGHT AND ELEMENTAL CONCENTRATIONS IN FOLIAGE OF MUSCADINE

Drew Bates*, C.P. Hegwood, Jr. and F.B. Matta, Mississipp State University, Truck Crops Branch Experiment Station, Crystal Springs, MS 39059.

A field experiment was established in 1980 to determine the effect of different combined levels of ammonium nitrate (196-695 $\mathrm{kg} / \mathrm{ha})$, potassium chloride $(56-196 \mathrm{~kg} / \mathrm{ha})$ and magnesium oxide (123-437 kg/ha) on 'Noble' and 'Magnolia' muscadine cultivars ( $\mathrm{Vitis}$ rotundifolia $\mathrm{Mich}$.). $\mathrm{NH}_{4} \mathrm{NO}_{3}$ rates of 196 to $695 \mathrm{~kg} / \mathrm{ha}$ did not produce significant differences in yields and pruning weights $(P=0.05)$. 'Noble' produced similar yields at the highest and lowest $\mathrm{N}$ rates, with equivalent rates of $\mathrm{K}$ and $\mathrm{Mg}$. $\mathrm{KCl}$ at 84 $\mathrm{kg} / \mathrm{ha}$ and $\mathrm{MgO}$ at $123 \mathrm{~kg} / \mathrm{ha}$ appeared to be adequate. Foliar levels of $K, \mathrm{Mg}$ and $\mathrm{Zn}$ were significantly different between treatments, but $P, C a$ and $F e$ were not $(P=0.05)$. High levels of foliar $K$ and $M g$ were associated with high treatment levels of $K$ and $\mathrm{Mg}$.

INFLUENCE OF GIBBERELLIC ACID AND FUNGICIDE EXPERIMENTS ON YIELD, QUALITY AND DISEASE CONTROL OF 'CHENIN BLANC' GRAPES IN SOUTHEAST TEXAS. Iva Suzanne Wilson, George Ray McEachern and J Dan Hanna, Department of Horticultural Sciences, College Station, TX 77843

Gibberellic acid and fungicide experiments were conducted in 1988 and 1989 to examine their effect on yield, quality and disease control of 'Chenin Blanc' grapes in Southeast Texas. Gibberellic acid applied 7 and 14 days prior to bloom at 2.5 and 5.0 ppm reduced the number of berries per ciuster in 1988 and 1989. The 2.5 ppm rate reduced berries and increased yield. The GA treatments also reduced bunch rot at harvest. Benomyl + Manzate fungicide treatments were superior to Nova and control in reducing bunch rot.

INFLUENCE OF CANOPY MANAGEMENT EXPERIMENTS ON YIELD, QUALITY AND DISEASE CONTROL OF 'CHENIN BLANC' GRAPES IN SOUTHEAST TEXAS.

Iva Suzanne Wilson, George Ray McEachern and J Dan Department of Horticultural Sciences, College station, $T X 77843$

Canopy management experiments of hedging and/ or leaf pruning, were conducted in 1988 and 1989 to examine their effect on yield, quality and disease control of 'Chenin Blanc' grapes in southeast Texas. Vines hedged and/or leaf pruned in May reduced bunch rot.. In 1988 all three treatments hat a significant lower juice pH at harvest than the control. The combination treatment also had a higher yield.

GHESTNUT PRODUCTION IN CHINA: A MODEL FOR DEVELOPMENT OF A CHESTNUT INDUSTRY IN THE SOUTHEASTERN U. $S$. J. D. Norton*, Department of Horticulture, Alabama Agr1cultural Experiment Station, Auburn University, Alabama 36849 and huang, Hong Wen, Hubel Academy of Agricultural Sclences, Wuhan, Peoples Republic of China.

The Chinese chestnut (Castanea mollissima) has been cultivated in China for more than 1000 years. During this period, indigenous cultivars and traditional cultivation practices have been used. China is the leading producer of Chinese chestnut (Castanea mollissima) with $37 \%$ of the world's production. In the last 4 years, improved cultivars and improved cultural practices have resulted in marked increases in production.

The leading provinces in Chestnut production are Hope1, Hubei, and Shandong. Severe injury, crop losses and tree mortal1ty have resulted from the chestnut gall wasp in China. Yields have increased greatly in Hubel province through cooperative breeding and developmental research between the Department of Horticulture Auburn University and the Hubei Academy of Agricultural Sciences. Two resistant seedlings from Auburn University are being utilized to.save the chestnut industry in China and posslbly worldwide. 
NEW FRUITS FROM CHINA

J. D. Norton, Department of Horticulture, Alabama Agricultural Experiment Station, Auburn University, Alabama 36849

Observations made during 3 six week periods of cooperative breeding and development research between the Department of Horticulture, Auburn University and the Hubei Academy of Agricultural Sciences indicates that different valuable germplasm of many fruits are present in China. Such cooperation provides the opportunity for the exchange of enhanced germplasm and cultivars to improve many of the horticulture crops of America and China. Resistance to diseases and insects and tolerance to drought, heat and nutrition stresses are found in the material.

The crops that appear to have the most immediate potential are the citrus with cold hardiness, kiwi of many improved types, pears of many types with fire blight reslstauce to chestnut blight and chestnut gall wasp, plums and plumcots with resistance to borers and many other crops such as raspberry, hawthorn, thorn pear and wolfberry.

\section{INFLUENCE OF IRRIGATION TREATMENTS ON PEACH GROWTH} AND YIELD

Susan M. Huslig* and Michael W. Smith, Department of Horticulture and Landscape Architecture, Oklahoma State University, Stillwater, OK 74078

Irrigation schedules were evaluated on 'Cresthaven' to determine if water could be conserved without reducing fruit size or yield. Tensiometers were used to schedule trickle irrigation in 1984-88. Treatments were no irrigation or irrigation when soil matric potential reached 40 or $60 \mathrm{KPa} 30$ $\mathrm{cm}$ deep. When production began in 1986, trees were either irrigated until Oct. or until after harvest (1-7 Aug.). In 1989, class A pan evaporation was used to schedule irrigation by replacing $100 \%$ evaporation. Trees were irrigated from bud break to harvest or Oct., beginning at stage III fruit growth to harvest or Oct., or not irrigated. The irrigation treatments were in factorial combination with an annual ryegrass ground cover or herbicidestrip. The ryegrass was seeded in Oct., then killed at the onset of stage III fruit growth. Water application was reduced $50 \%$ when irrigation was discontinued after harvest compared to irrigation until Oct. Non-irrigated trees had smaller trunks than irrigated trees; however, there were no differences in trunk size among irrigation treatments. Non-irrigated trees yielded less total fruit and fruit over 7-cm diameter than trees irrigated until Oct., but there were no significant differences in yield among irrigated trees. Flower bud density or fruit set was not affected by treatment. The orchard floor management did not affect tree growth or yield.

EFFECT OF APPLYING N THROUGH THE DRIP IRRIGATION SYSTEM ON PECAN TREE YIELD

Ray E. Worley*, J.W. Daniel, J.D. Dutcher, and K.A.

Harrison, Department of Horticul ture, University of Georgia Coastal Pla in Experiment Station, Tiftion, GA 31793

Nitrogen at rates of 112 or $224 \mathrm{~kg} \cdot \mathrm{ha}-1$ was applied to nonirrigated and drip irrigated mature pecan trees for 9 years. Some irrigated trees received $224 \mathrm{~kg} \cdot \mathrm{ha}^{-1} \mathrm{~N}$ either all broadcast or $\frac{1}{2}$ through the drip irrigation. Other drip irrigated trees received only $112 \mathrm{~kg} \cdot \mathrm{ha}-1$ all through the drip irrigation system. Fertigation was in 4 equal monthly doses beginning April 1 . Irrigation increased yield for 2 years for Schley and 3 years for Stuart. Nut size was increased by irrigation in 6 years for Schley and 8 years for Stuart. Applying $\frac{1}{2} \mathrm{~N}$ through the irrigation system caused no detrimental effect on yield or nut quality. The lower rate of $\mathrm{N}$ all applied through the drip irrigation system gave yield and nut quality as good as the higher rate either al1 broadcast or $\frac{1}{2}$ broadcast and $\frac{1}{2}$ fertigated.

INFLUENCE OF SPACING ON PEACH TREE PERFORMANCE Michael W. Smith*, Department of Horticulture and Landscape Architecture, Oklahoma State University, Stillwater, OK 74078

Performance of peach trees at seven spacings were evaluated over an 8-year period. Treatments were 'Garnet. Beauty' on Lovell spaced 3.0 or $4.6 \times 6.1 \mathrm{~m}$ and 4.6 or $6.1 \times 7.6 \mathrm{~m}$, self-rooted 'Garnet Beauty' spaced $1.0 \times$ 6.1 or $7.6 \mathrm{~m}$ then thinned to $3.0 \times 6.1$ or $7.6 \mathrm{~m}$ 4-years after planting, and self-ronted 'Garnet Beauty' spaced $1.0 \times 2.0 \times 5.5 \mathrm{~m}$ managed as a meadow orchard with alternate rows pruned to $30-\mathrm{cm}$ height after harvest. Trees spaced $4.6 \times 6.1 \mathrm{~m}$ or closer were mechanically hedged beginning 4-years after planting to $9 \mathrm{~m}$ tall and $6 \mathrm{~m}$ wide. Trees in all treatments, except 1.0 $\times 2.0 \times 5.5 \mathrm{~m}$, were trained to an open-center and hand-pruned annually. Trunk area and canopy area of trees spaced $3.0 \times 4.6 \mathrm{~m}$ or closer were smaller than trees in other spacings by 5 -years after planting. Cumulative yield per ha of trees spaced $1.0 \times 2.0 \times 5.5 \mathrm{~m}$ was grcatcr than yicld from other spacings 2- through 4-years after planting, then less 6 - and 7 -years after planting. There were no significant differences in yield/ha among the other spacing treatments. Fruil size was not affected by treatment. Yield efficiency of trees spaced 3.0 or $4.6 \times 6.1 \mathrm{~m}$ decreased by 8 -years after planting compared to trees spaced 4.6 or $6.1 \times 7.6 \mathrm{~m}$, indicating a reduction in fruit bearing growth. Hand pruning time was proportional to tree spacing.

EFFECT OF HYDROGEN CYANAMIDE (DORMEX) SPRAYS ON PEACH TREES SUFFERING FROM T.ACK OF WTNTER GHTLTTNG.

Arlie A. Powe $11^{*}$ and Ed Tunnell, Department of Horticulture, Auburn University, Auburn, AL 36849

Lack of winter chilling $\left(480 \mathrm{hrs}\right.$. at or below $7.2^{\circ} \mathrm{C}$ by $02 / 28 / 89$ ) occurred along Alabama's Gulf coast in the winter of 1988-89. Varieties requiring 650 hours of chilling or more were under stress. To evaluate hydrogen cyanamide (HC), a product used world wide to replace part of some fruit plants chilling req., a study was conducted along the: Gulf Coast using Bicentennial ( $700 \mathrm{hr}$.), Sentinel $(850 \mathrm{hr}$.) and Loring ( $900 \mathrm{hr}$. ) peach varieties. Full tree sprays (applied to drip with handgun) using $0, .5$ and $1 \%$ a.i. plus $.25 \% \times 77$ were applied $03 / 01 / 89$. Fruit buds were dormant to slight swell when sprayed. HC greatly enhanced rate and $\%$ of leaf bud break at the $1 \%$ conc., for all varieties. Rate and $\%$ of flowering were significantly increased at $1 \%$ conc. in Loring and Sentincl but ncarly all fruit dropped. Flowering, yield and fruit size of Bicentennial-were significantly improved at .5 and $1 \%$ conc. HC was effective in replacing lack of chilling in this variety.

EFFECTS OF EVAPDRATIVE COOLING ON GRAPE BUD HEAT SUMMATION AND ONTOGENY

WiTliam N. Lipe*, R. Louis Baumhardt, C.W. Wendt and David Rayburn, Texas Agricultural Experiment Station, Lubbock, TX 79401

The major production risk for grapes on the Texas High Plains is freeze injury to buds and wood due to deacclimation brought about by warm periods in late winter. Delaying plant development by any means would reduce risk from injury. Reducing cumulative heat summation between rest and bloom has resulted in delayed bloom on peaches but internal rest is not expressed in grapes. An evaporative cooling system using microsprinklers was applied to a Cabernet Sauvignon vineyard during Jan.-April 1989. The system provided a 25 second wetting period at 3 minute intervals anytime air temperatures exceeded $10^{\circ} \mathrm{C}$. Bud temperatures were monitored continuousiy wi th a data logger and correlated to cumulative budbreak and plant development. Significant bud cooling was achieved and by normal budbreak cooled buds lagged uncooled buds by $72 \%$ in degree days. A similar lag in budbreak was recorded early with some cooled buds breaking 3 weeks after most uncooled buds were open. Cooled plants continued to lag uncooled $\mathrm{plants}$ at bloom and even at harvest where ${ }^{0} \mathrm{~B}$ rix and $\mathrm{pH}$ were lower and total acids higher from cooled plots.

MAXTMIZING WATTR USE EFFICIENCY OF EVAPORATIVE COOLING SYSTEMS USED TO DELAY GRAPE BUDBREAK

R. Louis Baumhardt $*$, W. N. Lipe, David Rayburn, and $C$. W. Wend Texas Agricultural Experiment Station, Lubbock, TX 79401 Mild temperatures during late winter have caused early budbreak in grapes which resulted in freeze injury and significant crop losses in 1980 and 1988. Evaporative cooling of grapevines with microsprinklers when the air temperature exceeded $10^{\circ} \mathrm{C}\left(50^{\circ} \mathrm{F}\right)$ used $100 \mathrm{liters} / \mathrm{min} / \mathrm{hectare}$ of treatsd grapes ( 11 gallons/min/acre) and delayed budbreak for a period of 7 to 10 days. Methods of reducing the amount of water used while not reducing the cooling were evaluated. The average hourly difference between wet and dry bud temperatures, measured with thermocouples, were summed during the systen operation time and compared as a function of air temperature, wind speed, global radiation, and relative humidity limits. Iimiting the cooling system operation time as a function of air temperature, wind speed, or global radiation reduced cooling efficiency by approximately a one to one ratio. Limiting system operation to humidities less than 608 reduced the amount of water used by 338 , with only 98 reduction in cooling of water used by 338 , with only 98 reduction in cooling research from 25 seconds every three minutes to 25 in this research from 25 seconds every three minutes to 25 seconds every four minutes, total water conservation would increase to system insignificant changes in cooling efficiencies. These system modifications would reduce water application requirements to 50 


\section{Post Harvest}

A NEAR INFRARED INSTRUMENT FOR THE NONDESTRUCTIVE DETERMINATION OF SOLUBLE SOLIDS IN MELONS

Gerald G. Dull. Richard G. Leffler* and Gerald S, Birth, Russell Research Center, Athens, GA 30613

An instrument based on near infrared (NIR) reflectance techniques is described which is capable of determining nondestructively the percent soluble solids in whole honeydew, cantaloupe, and watermelon samples. It utilizes a tilting interference filter technology for wavelength scanning and silicon detector/amplifier for the detection of radiation which has penetrated through inner melon flesh. The standard error of prediction is of the order of 1.2 percent soluble solids for honeydew melons when compared with a standard refractometer analysis.

POSTHARVEST STORAGE CONDITIONS INFLUENCE SUGAR LEVEL AND RATE OF CARBOHYDRATE CONVERSION DURING PUREEING OF SWEET PQTATOES Paul W. Wilson ${ }^{*}$, David $H$. Picha and John M. Aselage IDepartment of Horticulture, Louisiana State University, Baton Rouge, LA 70803 and 2 Gerber Products Compnay, Fort Smith, AR 72917.

Changes in fructose, sucrose, and glucose were investigated in cured roots of 'Beauregard', 'Jewel' and 'Travis' sweet potatoes stored at $15^{\circ} \mathrm{C}$ and $1.5^{\circ} \mathrm{C}$ for $8 \mathrm{wk}$. Samples of 6 roots each in triplicate were analyzed at 2 wk intervals. At each interval, samples were also heated for $5,10,20$ or $40 \mathrm{~min}$. at $100^{\circ} \mathrm{C}$ to determine changes in rate of maltose. conversion. Roots stored at $15^{\circ} \mathrm{C}$ displayed gradual or no increase in sugars over the $8 \mathrm{wk}$. Roots stored at $1.5^{\circ} \mathrm{C}$ increased more rapidly in sugars, especially fructose, over the same time. 'Jewel' had the greatest increase in the sugars when stored at $1.5^{\circ} \mathrm{C}$. There was no consistent pattern of maltose conversion in roots stored at $15^{\circ} \mathrm{C}$ over the $8 \mathrm{wk}$ storage time. Roots stored at $1.5^{\circ} \mathrm{C}$ displayed a reduction in ability to convert starch to maltose upon heating. Less maltose was produced with increasing time of storag at $1.5^{\circ} \mathrm{C}$. 'Beauregard' and 'Jewe?' changed the most, while 'Travis' changed only slightly.

CULTIVAR RESPONSE OF OKRA TO CHILLING AND PACKAGINC P. Perkins-Veazie* and J. K. Collins. USDA-ARS, South Centra1 Agricultural Research Laboratory and Dept. Food and Nutrition, Oklahoma State University., Lane, OK 74555.

okra pods are highly perishable due to a high respiration rate and chilling sensitivity. The purpose of this experiment was to evaluate ekra cultivar response to package and storage temperature. Freshly harvested 'Annie Oakley', 'Blondy', 'Burgundy', 'Clemson Spineless' and 'Emerald' okra pods were placed in plastic boxes and shrinkwrap bags. Pods were evaluated for weight loss, chilling infury and.electrolyte leakage during 8 days of storage at 12.5 and $3^{\circ} \mathrm{C}$. Weight loss was similar for all cultivars at both temperatures, but it was much less when pods were stored in bags compared to boxes. Percent electrolyte leakage was similar for all cultivars before storage. 'Blondy' displayed the most severe chilling injury after 8 days of storage at $3 C$ while 'Emerald' had few symptoms of chilling injury. After 8 days of storage, all cultivars except 'Emerald' had increased electrolyte leakage. These results indicate that okra pods have Increased membrane permeability with chilling infury, and the degree of chilling injury may differ with cultivar.

GENOTYPE AND PRODUCTION ENVIRONMENT INFLUENCES EFFECTIVENESS OF CA STORAGE FOR SHORT-DAY ONIONS

Doyle A. Smittle* and M. Darlene Mercer, University of Georgia Coastal Plaín Experiment Station, Tifton, GA 31793 Two lots of' 'Granex 33' and a 'Walla Walla' lot of onions were stored in a Georgia CA facility designed to produce $1 \mathrm{C}, 70-75 \% \mathrm{RH}, 3 \% \mathrm{O}, 5 \% \mathrm{CO}, 92 \% \mathrm{~N}$ and an air flow of $1 \mathrm{~m}^{3} / \mathrm{Mg}$ onions. Subsamp 7 es of these lots were also stored in air at 1C. Three lots of 'Granex $33^{\prime}$ onions and one lot of
'Texas 1015Y' onions were stored in a CA facility in Michigan under similar conditions.

About $85 \%$ of the onions were marketable after 5 months of $C A$ in Georgia and 2 wccks shelf-1ife. Less than $25 \%$ of the onions stored in air at $1 \mathrm{C}$ were marketable after a similar storage and shelf-life period. All 'Walla Walla' bulbs decayed.

Shelf-life differences occurred among the 'Granex 33' lots grown in Georgia and the 1015 lots grown in Texas after 5 months of CA storage in Michigan. Two of the 'Granex 33' lots stored fairly well (70-75\% marketable) while the third lots stored less we 11 (40\% marketable). The Texas 1015 onions stored poorly (0-15\% marketable).

CA STORAGE INHIBITS CHILL INJURY OF MUSCADINE GRAPE M. Darlene Mercer* and Doyle A. Smittle, Department of Horticulture, University of Georgia Coastal Plain Experiment Station, Tifton, GA 31793

'Fry' and 'Granny Val' muscadine grapes (Vitis rotundifilia) were stored at IC for two, four, and six weeks in himidified flow-through atmospheres of air, $0 \% \mathrm{CO}_{2}-5 \% \mathrm{O}_{2}, 5 \% \mathrm{CO}_{2}-5 \% \mathrm{O}_{2}, 10 \% \mathrm{CO}_{2}-5 \% \mathrm{O}_{2}$, and $15 \% \mathrm{CO}_{2}-5 \% \mathrm{O}_{2}$. Weight loss, grade, $\mathrm{pH}$, acidfty, soluble solids, sugars and sensory evaluations were made upon removal from $1 \mathrm{C}$ storage. Chill injury ratings were made after 0,24 , and 48 hours at $27 \mathrm{C}$. 'Fry' muscadine grapes had a better storage life than did 'Granny Val!. High $\mathrm{CO}_{2}$ atmospheres extended the storage life of both cultivars. Severe chill injury symptoms resulted after 4 or 6 weeks of $1 \mathrm{C}$ storage in air. $\mathrm{High} \mathrm{CO}_{2}$ atmospheres inhibited chill injury of both 'Fry' and 'Granny Val' grapes. No chill injury to either cultivar occurred after six weeks of storage in the $15 \% \mathrm{CO}_{2}-5 \% \mathrm{O}_{2}$ atmosphere.

EFFECT OF CONTROLLED ATMOSPHERE STORAGE ON PEACH QUALITY. Ahmed F. El-Shiekh* and David H. Picha, Department of Horticulture, Louisiana State University, Baton Rouge, LA 70803 Peaches stored in air for 40 days at $O C$ developed severe internal breakdown and poor quality after transferring them to $20 \mathrm{C}$ to ripen. Comparable fruit stored under controlled atmosphere $\left(1 \% \mathrm{O}_{2}+5 \% \mathrm{CO}_{2}\right)$ and then ripened at $20 \mathrm{C}$ had no breakdown and retained good quality. Fruit stored under CA had less reducing sugars but more sucrose than air stored fruit. Fruit $\mathrm{pH}$ increased and titratable acidity decreased over a 40 day storage period. Citric acid increased silghtly while malic acid decreased during storage. Little or no differences in overall acidity and individual organic acids existed between $C A$ and air storage. Little or no change in individual phenolic acid content occurred during storage or between CA and air storage. Internal color darkened and became redder with storage. CA stored fruit was significantly firmer than air stored fruit. Sensory evaluation indicated $C A$ stored fruit was more acidic, sweeter, and had better overall flavor than air stored fruit.

SENSORY AII'RIBU'TES OF JUICE PROCESSED FROM APPLES TREATED WITH CALCIUM CHLORIDE PRIOR TO STORAGE.

Robert J. Portillo*1, Carl E. Sams ${ }^{2}$, William S. Conway ${ }^{3}$ Jimuie L. Collins ${ }^{2}$, and Marjorie P. Penfield ${ }^{2}$. Depts. of Plant and Soil Science ${ }^{1}$ and Food Technology and Science ${ }^{2}$, University of Tennessee, P.O. Box 1071, Knoxville, TN 37901 , and USDA, Hort. Crope Quality Lab ${ }^{3}$, Beltsville, MD 20705. 'Golden Delicious' and 'Red Rome' apples were pressure infiltrated ( $69 \mathrm{kPa}$ for 2 or $4 \mathrm{~min}$ ) at harvest with $0,1,2$, 3 or $4 \%$, and $0,2,4,6$ or $8 \% \mathrm{CaCl}_{2}=$ solutions $(w / v)$ respectively, and placed in $0^{\circ} \mathrm{C}$ storage. Juice was extracted from the apples after $0,2,4$ or 6 months in storage. Sensory evaluation of the juice was conducted to determine if $\mathrm{CaCl}_{2}$ concentration affected color, off-flavors, suspended particles or overall acceptability of the juice. Juice color was judged lighter with increased $\mathrm{CaCl}_{2}$ in both cultivars. Detection of off-flavors decreased as $\mathrm{CaCl}_{2}$ was increased in juice from 'Red Rome'; whereas, off-flavors increased as $\mathrm{CaCl}_{2}$ was increased in 'Golden Delicious' juice. $\mathrm{CaCl}_{2}$ treatments decreased suspended particles in both cultivars. As $\mathrm{CaCl}_{2}$ was increased overall acceptability of juice from 'Red Rome' increased, while acceptability of juice from 'Golden Delicious' decreased. 
DISTRIBUTION OF CALCIUM AND OTHER STRAWBERRY FRUIT NUTRIENTS AS EFFECTED BY SUPPLEMENTAL CALCIUM FERTILITY

D. J. Makus* and J..R. Morris, USDA-ARS, Booneville, AR 72927 and Dept. Food Science, University of Arkansas, Fayetteville, AR 72703

Fruit of 'Cardinal' and 'Fern' were harvested, acid washed, decapped, and frozen to $-20^{\circ} \mathrm{C}$ on 6 May 88 . Frozen fruits were subsequently divided into six parts. The upper and lower fruit halves were further separated into pulp, dermal, and secd components. Nutrients increased from the pulp to the seed with the exception of $A 1$. $K$ was most abundant in receptacle tissue (but not in seeds) followed by $\mathrm{P}, \mathrm{Ca}$, and $\mathrm{Mg}$. $\mathrm{K}, \mathrm{Ca}, \mathrm{Mg}$, and $\mathrm{Cu}$ were higher and $\mathrm{Mn}$ and $\mathrm{Zn}$ lower in pulp upper tissue than lower pulp tissue. $\mathrm{K}, \mathrm{Ca}$, $\mathrm{Na}, \mathrm{Zn}$, and $\mathrm{Al}$ were higher in upper dermal tissue than in lower dermal tissue. $\mathrm{Ca}, \mathrm{Cu}$, and $\mathrm{B}$ were higher and $\mathrm{Mg}$ and $\mathrm{Mn}$ lower in upper octanes than in lower achenes. In descending order, $\mathrm{Ca}, \mathrm{P}, \mathrm{Mg}$, and $\mathrm{K}$ were the most abundant seed nutrients. Supplementing strawberries with $904 \mathrm{Kg} \mathrm{Ca} / \mathrm{ha}$ increased only the seed Ca levals. All levels of supplemental pre-harvest $\mathrm{Ca}$ were found to reduce postharvest decay. Although 'Fern' was higher in seed $\mathrm{Ca}$, with similar Ca levels in receptacle tissue, fruit decay was higher than in 'Cardinal'. There appears to be no clear relationship between fruit decay and $G$ distribution within the fruit.
LONG-TERM EFFECT OF SOIL SOLARIZATION ON CONTROLLING ROOT-KNOT NEMATODES IN SWEETPOTATO C. Stevens*, V. A. Khan, A. Y. Tang, C. R. Bonsi Dept. Agri. Sci. Tuskegee University, Tuskegee, AL 36088 and M. A. Wilson, Dept. Agri. Southeast Missouri State University, Cape Girardeau. MO 63701

A three year study involving solar heating of soil (soil solarization) with clear polyethylene wulch demonstrated for two years, control of root-knot nematodes (Meloidogyne incognita). The population of $M$. incognita was reduced $>90 \%$ in the $0-30 \mathrm{~cm}$ depth of solarized soil. The number of eggs per gram root recovered and the root gall index from 'Georgia-Jet' sweetpotatoes were reduced (92-98\%) by soil solarization. Growth and yield were enhanced in solarized soil. The beneficial effects of solarization was observed in the second year following two additional cropping cycles of collard greens and sweetpotatoes.

\section{Sweet Potato Collaborators}

FUSARIUM LATERIFIUM CAUSES SWEETPOTATO CHLOROTIC LEAF DISTORTION

C. A. Clark, R. A. Valverde, J. A. Wilder-Ayers, and P. E. Nelson, Dept. Plant Path. \& Crop Phys., Louisiana Agric. Expt. Sta., LSU Agric. Center, Baton Rouge, 70803 and Fusarium Res. Center, Penn. State Univ., Univ. Park, 16802. Symptoms of chlorotic leaf distortion (CLD) develop on vigorously growing sweetpotato (Ipomoea patatas) plants during sunny weather. They include chlorosis and twisting of young, expanding leaves and the appearance of white material on the adaxial leaf surfaces. The white material consisted of extramatrical fungal mycelia and Fusarium macroconidia. Fusarium lateritium Nees was isolated from surface-sterilized vine segments, leaf primordia, apical meristems, flower parts and true seeds of plants with CLD. Meristem-tip-culturederived plants (mericlones) did not develop symptoms when grown for extended periods under disease-conducive conditions in the greenhouse. The fungus was not isolated from mericlones or other plants which had remained symptomless in the greenhouse but was isolated from lower nodes of symptomless plants from growers' fields. Symptoms developed on $84 \%$ of 185 mericlones of nine sweetpotato genotypes inoculated with $F$. lateritium isolated from CLD-affected plants. The pathogen was reisolated only from inoculated mericlones.

\section{DATABASE FOR SWEETPOTATO BREEDING PROGRAMS}

P.C. St. Amand ${ }^{\star}$ and D.R. La Bonte, Department of Horticulture, ouisiana State University, Louisiana Agricultural Experiment Station, Louisiana State University Agricultural Center, Baton Rouge, LA 70803

A user-friendly, menu driven, database program was developed to facilitate storage, retrieval, and manipulation of data associated with a sweetpotato breeding program. The database is written in FoxBASE+ for IBM and compatible persona 1 computers. -The database consists of a variety of test options with statistical capabilities for analysis of raw test data for commonly evaluated factors used to screen sweetpotato selections. The database also contains options which permit the user to query the stored data. An important feature is the summarization of test data for individual selections based on all the tests it has been entered into. Overall means, SDs and comparisons with user specified checks are listed in a printout for each factor along with morphological descriptors, parentage, and a note section. The database also assists the user in field research through recording of plot plans, data collection forms and related data query options.
WHITE ASPARAGUS PRODUCTION WITH OPAQUE PLASTIC ROW COVERS D. J. Makus* and A. R. Gonzalez, USDA-ARS, Booneville, AR 72703 and Dept. Food Science, University of Arkansas, Fayetteville, AR 72703

Black and white plastic row covers were established over field-grown 'Jersey Giant' asparagus on 10 Mar 89. Season soil temps in uncovered, white, and black plastic treatments were $17.4,15.9$, and $16.8^{\circ} \mathrm{C}$, respectively. Night air temp under plastics was about $1.4^{\circ} \mathrm{C}$ higher than no plastic. Day temps under black plastic were typically $>10^{\circ}$ higher than no cover. Temps under white plastic were intermediate. Spears were cut for 7 weeks beginning on 27 March. Black plastic improved early yield only at the third cutting week. There was no consistent plastic cover effect on spear diameter. Marketable and total yield were improved with the use of plastics. Spear number/ha was not affected. Spear weight (after trimming to $15 \mathrm{~cm}$ length) was greater when grown under plastic, whereas spear length was reduced. There were no differences between treatments in spear fiber, but spears grown under plastic covers had higher soluble solids and nitrates, and lower ascorbate, protein and phenolic levels than did uncovered spears. Very little chlorophyll and carotenoids were produced in the absence of light, but there whe a colof intensify difference between spears grown under

SWEET POTATO GROWTH AND ROOT DEVELOPMENT IN FRITTED CLAY MEDIA P. J. Ndolo* and E. G. Rhoden, George Washington Carver Ag. Experiment Station, Tuskegee University, Tuskegee, AL 36088 Root growth of sweet potato [Ipomoea balalas (L) Lam.] cvs 'TI-82-155', 'Centennial' and 'Rojo Blanco' in coarse fritted clay soil, was investigated under greenhouse conditions. The sweet potato cultivars were harvested at 41 and 82 days after planting. Dry weight of fibrous roots of all cultivars were similar at day 41 . Fibrous root weight of 'Rojo Blanco' increased by $5 \%$ while those of the other cultivars increased by $168 \%$. Mean fibrous root length per centimeter depth was not significantly different among cultivars. Although fresh weight of storage roots of 'Rojo Blanco' was significantly lower than those of the other cultivars, their dry weights were similar. 'TI-82-155' and 'Rojo Blanco' had fewer storage roots compared to the other cultivars, however, storage root length of ' $T 1-82-155^{\prime}$ or 'Rojo Blanco' was greater than that of 'Georgia Jet' or 'Centennial'. Length to diameter ratio of the storage root of 'Rojo Blanco' was significantly greater than that of 'TI82-155' and 'Georgia Jet'. 
BREEDING MELONS FOR DISEASE IN CHINA

J. D. Norton, Department of Horticulture, Alabama Agricultural Experiment Station, Auburn University, Alabama 36849

The watermelon has been cultivated in China for more than 1000 years. During most of this period, indigenous cultivars and traditional cultivation practices were used. In the last decade, many improved cultivars have been developed and the use of plastic mulch and other improved cultural practices have been utilized. China has become the largest producer of watermelons with the production area increasing to. 1 million hectares and 15 million tons in 1988.

Watermelons are grown in almost all production areas of China. The production areas are: the Northwest inland dry region, the North China plain region, and the Changjlang (Yantzi river) valley rainy region . Severe infury and crop losses occur from Fusarium wilt, (Fusarium oxysporium v. niveum) anthracnose (Colletotrichum laginarium), and gummy stem blight (Didymella bryonaea). Cooperative breeding and developmental work was initiated between the Dept. of Horticulture, Auburn University and the Hubel Academy of Aggricultural Science and the Hubei Agricultural College, Jing zhou to evaluate cultivar and germplasm and to develop multiple disease resistant melons that produce high yields of excellent quality fruit.

EFFECT OF CHANNEI DEPTH ON YIELD OF SWEET POTATOES GROWN HYDROPONICALLY

C. Morris, * D. Mortley, P. Loretan, C, Bonsi and W. Hill, George Washington Carver Agricultural Experiment Station, Tuskegee University, Tuskegee, AL 36088

The potential of the sweet potato as a food source for future long-term manned space missions is being evaluated for the National Aeronautics and Space Adninistration's (NASA) Controlled Ecological Life Support System (CELSS) Program. Several experiments have shown that the sweet potato can be grown hydroponically. However, an evaluation of the NASA fan-shaped Biomass Production Chamber (BPC) channel was initiated to determine if channel depths influenced the yield of hydroponically grownsweet potatoes. Three channel depths were studied, $5 \mathrm{~cm}(2 \mathrm{in})$ standard NASA BPC channel, $10 \mathrm{~cm}$ ( 4 in) channel and $15 \mathrm{~cm}$ ( 6 in) channel. The experiment consisted of one replication. The results show that channel depth does effect the yield of storage roots. The $15 \mathrm{~cm}$ depth channel provided the most consistent yield with all channels having significantly different fresh storage root yields in the replicate.

PHOTOMORPHOGENIC GROWTH OF WATERMELON AS INFLUENCED BY LIGHT TRANSMISSION THROUGH ROW COVER MATERIALS

Heather $H$. Friend* and Dennis R. Decoteau, Department of Horticulture. Clemson University, Clemson, SC 29634-0375

Alterations in spectral distribution as affected by selective light transmission of row cover materials were evaluated for effects on early watermelon (Citrullus lanatus cv. Sugar Baby) growth and development. Selected commercially available row covers were analyzed for light transmission properties. Results suggest that row cover materials function as selective light filters and influence parameters of light that can affect plant morphogenesis. Clear polyethylene row covers caused little variation in transmitted PAR (photosynthetically active radiation) and photomorphogenic light (FR/R and blue light). White polyethylene row covers decreased the transmitted PAR and blue light but had no effect on the FR/R ratio. Watermelon plants grown under a white polyethylene row cover with a greater FR/R ratio of light were taller (longer stems) and had longer petioles than plants grown under a clear polyethylene row cover with a smaller transmitted FR/R ratio.

ECONOMIC RETURNS ON NITROGEN FERTILIZATION EXPERTMENTS FOR PIJMPKINS AT TUSKEGEE, ALABAMA

N. Baharanyik, E. G. Rhoden and V. Khan, Department of Agricultura1 Sciences, Tuskegee University, Tuskegee, AL 36088

This study examined the potential economic returns of using four different sources of nitrogen on 'calabaza' pumpkins, a tow moisture variety consumed as starch by many foreign nationals. Yields were $12.4,12.6,8.2$ and $9.5 \mathrm{~kg} /$ plant for ammonium nitrate, sodium nitrate, ammonium sulfate and urea, respectively. Assuming 1989 farm gate prices in Alabama and other appropriate cost for vaious inputs used, the estimated return at $\$ 0.30 / 1 \mathrm{~b}$ of pumpkin was $\$ 10,003$, $\$ 10,115, \$ 6,105$ and $\$ 7,371 /$ acre for different sources of nitrogen, respectively. The relatively higher return from sodium nitrate use explains the use of this source of nitrogen un renled land. A sensitivity analysis of the enterprise budgets shows a breakeven price between $\$ 0.02$ and $\$ 0.10 / 1 \mathrm{~b}$.
DOUDLE-CROPPING CUCUMBER AND TOMATOES TO REDUCE THE COST OF STAKING CUCUMBER

H. Y. Hanna*, R. J. Edling, and A. J. Adams, Citrus . Louisiana State University, Port Sulphur, LA 70083

Cucumber (Cucumis sativus L.) double-cropped with tomato (Lycoperscum esculentum MiIl.) and staked with the double-cropping system needed less than half the man-hours to stake than the standard system. Tomato rods and tomato plants were not removed which could result in further cost reduction. Glyphosate [N-(phosphonomethly) glycine] was used to kill all the vegetation at a cost of $\$ 45-\$ 50 /$ acre. Double-cropped cucumber produced comparable yields of high quality fruits to cucumber staked by the standard system. The standard system produced more No. 2 fruits resulting in more marketable yield. The 2 systems produced an equal percentage of culls or rots. In-row spacing of 22.5 or 30 $\mathrm{cm}$ appeared to be the best choice when cucumber was staked by the double-cropping system. The side of the row where cucumber was planted ald not affect the yield significantly. However, planting cucumber on both sides gave the highest yield. It appears that there was enough residual fertilizer left over after tomatoes to produce the cucumber crop.

GENOTYPIC AND ENVIRONMENTAL EFFECTS ON CARBOHYDRATE DISTRIBUTION IN POTATO

Peng Hwang* J.Creighton Miller, Jr. and B.Greg Cobb,

Department of Horticultural Sciences, Texas A\&M University, College Station, TX 77843-2133

Field studies were conducted at two Texas locations: Lubbock, near the major production area for Texas potatoes, and College Station which is hotter and more humid. Early and late plantings were established at each location to compare cool and hot growing conditions. Nine genetically diverse cultivars, including those previously reported to be heat resistant or susceptible, were used in this study. Results indicated that the distribution of soluble carbohydrate and starch differed significantly among plant parts. In leaves and stems, glucose and fructose were the major soluble carbohydrates, while sucrose was the major soluble carbohydrate in tubers. Total soluble carbohydrate and starch content in leaves, stems and roots from the early plantings were significantly higher than those from the late plantings. Inositol increased significantly in the College Station late stress environment.

PERFORMANCE OF A WIDE RANGE OF ASIAN VEGETABIES AT TWO LOCATIONS IN EAST TEXAS

J. Anderson* and D. Creech, Department of Agriculture, Stephen F. Austin State University, Nacogdoches, TX 75962

The population of U.S. Asians will increase by $41 \%$ and reach 12 million by the year 2000. Chinese cabbage, Pak Choi, Daikon, and Bitter melon have moved out of the ethnic market and are now in mainstream outlets. This study targeted a diverse range of cool and warm-season crops. Besides those listed above, this study evaluated varieties of Asian greens, Chinese brocolli, Allium, edible soybeam, melon, squash, cucumber, edible Chrysanthemum, amaranth, winged bean, yardlong bean, and edible soybean. A randomized complete block design was utilized, with three replications of row length, varying from 10 to 33 feet, depending on species tested. Direct seedlings of cool-season crops in February and September, 1989 resulted in good market quality and yield of many varieties. Work in 1990 will focus on width of the market window, market information, and grower access to markets.

\section{WATERMELON YIELD AFFECTED BY PLANT POPULATION,} PLANT NUMBER AND PLASTIC MULCH

D. C. Sanders*, J.R. Schultheis, P.P. David and M. R. McMurtry, Horticultural science North Carolina state University, Raleigh, N.C. 27695

We evaluated high plant population of watermelons when grown on black plastic with drip fertigation. We grew watermelons in $1.5 \mathrm{~m}$ or $1.8 \mathrm{~m}$ centered rows, with one or two plants per hill, at spacing from 0.45 to $1.5 \mathrm{~m}$ in-row. Single plants constantly out yielded 2 plant hills and produced bigger melons. Large (over $9 \mathrm{~kg}$ ) melon yields were not different at in-row spacing of $0.6 \mathrm{~m}$ and greater. However, the 5.4-9kg melons "pee wees" produced more yield as in-row spacing decreased. Thus total marketable melon yields increased as inrow spacing decreased to $0.45 \mathrm{~m}$ up to 21,000 melons and $135 \mathrm{~T} / \mathrm{ha}$. Plastic increased yield 2 to 4 times depending on the spacing. If small watermelons can be sold, single plants at $0.45 \mathrm{~m}$ spacing provided the greatest return for the plastic-dripfertigation system. 
THE USE OF LOW RATES OF CLOMAZONE ON WATERMELON H. E. Hohlt*, H. P. Wilson, and T. E. Hines, Eastern Shore Agricultural Experiment Station, Painter, VA 23420 During 1989, clomazone (Command) was applied pretransplant or preemergence to transplanted and seeded watermelon (Citrullus lanatus, cv. Charleston Gray), respectively. Rates of 280,414 , and $560 \mathrm{~g} \mathrm{ai} \cdot \mathrm{ha}^{-1}(0.50,0.75,1.0 \mathrm{pt} / \mathrm{A})$ clomazone were applied to a Bojac sandy loam. Plots were rated for percentage weed control 21 DAT. Control of common lambsquarters [Chenopodium album (L.)], large crabgrass [Digitaria sanguinalis (L.) Scop.], and smooth pigweed (Amaranthus hybridus L.) increased with rate although smooth pigweed control was low. A significant phytotoxic injury characterized by bleaching and reduced growth occurred at all rates on melon transplants. No significant phytotoxicity occurred in seeded plots 35 DAT. Vine length $(\mathrm{cm})$ was recorded 42 DAT. Vine length was reduced significantly at the $560 \mathrm{~g} \cdot \mathrm{ha}^{-1}$ rate in transplants. Vine length of seeded watermelons was not significantly affected.

BELL PEPPER GROWTH AND PRODUCTION AS INFLUENCED BY END-OF-DAY SUPPLEMENTAL LIGHT-PRIMING OF TRANSPLANTS

Dennis R. Deculeau* and Heather H. Friend, Department of Horticulture, Clemson University, Clemson, SC 29634-0375

The influence of end-of-day (EOD) supplemental light-priming on pepper (Capsicum annuum cv. Keystone Resistant Giant No. 3) transplants was investigated for possible residual growth effects on subsequent plant growth and fruit production. Greenhouse grown pepper transplants were fluorescent light-primed for one hour prior to dusk for three weeks in 1988 and four weeks in 1989 and then transplanted to the field. EOD fluorescent light-priming of pepper plants reduced the height, leaf area, dry weight, fruit number, and fruit weight as compared to non-treated plants prior to first harvest. EOD fluorescent light-priming of pepper transplants had little effect on early and total fruit production. These results suggest that EOD fluorescent light-priming of transplants that affect early pepper growth in the field have little residual influence on subsequent fruit production.

SEX RATIOS AND FRUIT CHARACTERISTICS OF CRIMSON SWEET WATERMELONS GROWN UNDER VISPOTE ROW COVER AND PLASTIC MULCH

V. A. Khan*, and C. Stevens Dept. Agri. Sci. Tuskegee University, Tuskegee, AL 36088

Staminate and pistillate flower production and fruiting characteristics of 'Crimson Sweet' watermelons were evaluated under visPore row cover plus clear polyethylene mulch (VCM), VisPore row cover p1us black polyethylene mulch (VBM), clear polyethylene mulch (CM), black polyethylene malch (BM) and bare soil (BS). vCM produced significantly higher numbers of pistillate and staminate flowers than other treatments. A11 mulched and mulched $p l u s$ VisPore treatments were significantly different from BS with regards to the 1st nodal position of the staminate and pistillate flowers. Fruit-set among the treatments between 53-55 days after transplanting were: $100 \%, 75 \%, 59 \%$ and $32 \%$ for VCM, VBM, CM and BM, respectively. Average number of fruits per plant were: $4,3,3,3$ and 1 for VCM, VBM, CM, BM and BS, respectively.

LONG-TERM EFFECTS OF SOIL SOLARIZATION ON THE GROWTH RESPONSE AND SOIL FERTILITY OF COLE CROPS C. Stevens*, V. A. Khan, J. Y. Lu, A. Y. Tang

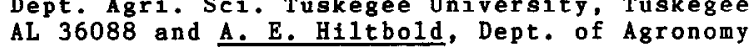
\& Soil, Auburñ University, AL 36849

Partial steam and chemical sterilization of soil rich in organic matter increased the soil nutrients, little information exists with regard to the effect of soil solarization (SS) in this regard. A study was established to determine the effects of $S S$ in combination with wheat residue and subsequent crop residue on increased growth response. (IGR) of cole crops and soil fertility for two yeafs. SS for 90 days increased $k$, $P$, $\mathrm{Ca}^{++}$and $\mathrm{Mg}^{+{ }^{+}} 3$ times more within five months after SS. The SS effect released higher levels of total $\mathrm{N}$ in the soil. However, increase levels of $\mathrm{N}$ was lower than that required for maximum IGR of collard. The IGR of cole crops without fertilizers was higher in SS plots as compared to bare soil. The IGR of collard was evident almost two years after SS.
THE EFFECT OF SOIL SOLARIZATION ON THE MICROFLORA ASPECTS OF SOIL FERTILITY

C. Stevens*, V. A. Khan, A. Y. Tang Dept. Agri. Sci. Tuskegee University, Tuskegee, AL 36088 and R. M. Cody, Dept. of Botany and Microbiology, Auburn University, AL 36849 Field plots on Norfolk sandy loam soil at Tuskegee and Eufaula, AL were treated by soil solarization (SS). Samples rhizsosphere (R) and nonrhizosphere soil from cole crop and strawberry plots were collected and assayed with selective media for population densities of microbes involved in organic decomposition and mineralization. Microflora population densities of bacteria, actinomycetes and fungi increased $2-7$ folds in the solarized compared to the bare soil (BS). Microflora population densities in the soils involved in cellulose and protein decomposition, ammonication, nitrification, phosphate mincralization were greater in solarized soil compared to BS. Nitrogen-fixing bacteria in $R$ soil 7 months after SS was higher when compared to BS at Tuskegee, but was reduced 50 folds 18 months after SS.

INFLUENCE OF FERTILIZER PLACEMENT UNDER PLASTIC ON YIELD AND NUTRIENT UPTAKE OF TRAMSPLANTED TOMATOES.

DESHOND MORTLEY*, V. KHAN, C. BONSI AND E. RHOOEN, George Washington Carver Agricultural Experiment Station, Tuskegee University, Tuskegee, ML 36088

Fertilizer placement under plastic was studied on 2 tomato cultivars ('TI-130' and 'Floradade') during 1989. Treatments were 1, 2 or 3 increments of fertilizer broadcast, banded, broadcast/banded of banded with 1 or 2 sldedressings and a check. Fertllizer applled was NPK al 135-90-84 kg-ha-1 as a ammonium nitrate, triple superphosphate and murlate of potash, 10cm to each side of the plants and $10 \mathrm{~cm}$ deep. Vine, total, marketable and early yields for lower rotes either Br or Ba werc as good as those of the full rate $\mathrm{Br}$ or Ba with 2 sidedressings (Ba/SD2). Leaf N, P, K, Ca and Mg for ' $\mathrm{TI}-130$ ' were not affected by placement. The Ba/SD2 placement increased leat $\mathrm{N}$ for 'Floradade' but leat Ca was reduced in all treatments vs the check. Leat Mn was increased markedly by placements Involving broadcasting at all rates.

EFFECT OF SPACING ON YIELD OF SWEET POTATOES GROWN USING THE NUTRIENT FILM TECHNIQUE (NFT)

Desmond Mortley*, Conrad Bonsi, Philip Loretan, Walter Hill, and Carlton Morris, George Washington Carver Agricultural Experiment Station, Tuskegee University, Tuskegee, AL 36088 Greenhouse experiments were conducted to evaluate the effects of spacing within and between growth channels on the yield of 'TI-155' sweet potatoes grown hydroponically using the nutrient film technique (NFT). Spacings within channels were $12.7,17.8$ and $25.4 \mathrm{~cm}$ whereas between growth channels the spacings we re $12.7,25.4$ and $38.1 \mathrm{~cm}$. Vine cuttings ( 15 $\mathrm{cm})$ placed in each channel $(0.15 \times 0.15 \times 1.2 \mathrm{~m})$ were supplied with a modiffed half-Hoagland solution and grown for 120 days. Storage root number, fresh and dry weights and follage fresh and dry weights tended to increase as spacing between channels increased. Spacing of plants within channels had no significant effect on any sweet potato growth responses.

AN ECONOMIC EVALUATION OF TWO YEARS OF ON-FARM PLASTIC MULCH EXPERIMFN'L'S FOR SELECI'ED VEGETABLE C.KOPS IN BUTLER COUN'YY, ALABAMA

N. Baharanyi*, C. Stevens, V. Khan and A. Siaway, Department of Agricultural Sciences, Tuskegee Universily, Tuskegee AL 36088

This study evaluated the potential economic returns of two years of on-farm plastic mulch experiments for 'Market Topper' cabbage and 'Vates' collard greens conducted on a field with serious weed and nematode problems in Butler County, Alabama. Assuming 1987 and 1988 wholesale prices for vegetable crops in Alabama and other appropriate prices for various inputs used, and after adjusting the cost of plastics in the enterprise budgets for having used the same in the two years, the estimated return for cabbage harvested from plastic mulch experiments was 5 times greater in 1987 $(\$ 2,776.83$ and $\$ 551.02)$ and more than 10 times in 1988 $(\$ 2,775.00$ and $\$ 49.40)$ than from non-covered field. The estimated return for collard greens from plastic mulch experiments was also 5 times greater in $1987(\$ 1,416.70$ and $\$ 287.96$ ) and more than 10 times in 1988 ( $\$ 339.50$ and $-\$ 444.20$ ) than from non-covered field. Questions remain as to the perceived economic benefits for other farmers and the nonbiodegradable nature of the plastic used. 
TAM VERACRUZ-A NEW MULTIPLE VIRUS RESISTANT HOT JALAPEÑO PEPPPER-Ben Villalón, Texas Agricultural Experiment Station, Wes laco, TX 78596

TAM VERACRUZ is a multiple virus resistant (MVR), open poll inated pepper cultivar developed by Texas Agricultural Experiment Station at Weslaco. This pungent, cyl indrical (fruit with blunt end and cuticular cracks) jalapeño variety possesses high levels of genet ic res istance to several isolates of TEV (Texas, Cal ifornia and Culiacan isolates). It also carries resistance to local virulent isolates of PVY, PellV, TRSV, CMV, and TMV. This genotype combines the desirable horticultural characteristics of commercial standards and MVR genes derived from PI 342947, PI 264281 AC 2207 and Avelar. Additionally, 'TAM Veracruz' has the ability to set fruit at temperatures above 35C. It has a concentrated flower hab it, sets fruits earlier and matures more uniformly than its progenitor 'TAM Mild Jalapeño-1'. It is predominatly single stemmed and.will support a good heavy set of large thick, fruit which can be mechanically harvested. It is well suited for fresh market consumption in salads; or as a processed product, pickled whole, sliced as "nacho" rings or diced for use in picante sauces. This pepper is as hot as Jalapeño $M$.

YIELD OF CUCUMBER SEEDED WITH GEL AIJD FUNGICIDES IN COINSERVATION TILLAGE

Suhas R. Ghate, Donald R. Sumner, and Sharad C. Phatak, The University of Georgia, Coastal Plain Station, Tifton, GA 31793

Cucumber crop was established in conservation tillage from ge1-sowr germinated seed. Fungicides (flutolanil + metalaxy1) were mixed with gel or applied as a drench after seeding to control Rhizoctonia and Pythium seedling diseases. The benefit of mixing fungicides with gel was similar to drenching the seeded area with fungicides. There was no added advantage of using germinated seed for cucumber production in conservation tillage. In fact, germinated seed was more susceptible to fungal diseases in the absence of fungicides. Crop yield was greater in conventionally-prepared soil than in conservation tillage.

INFLUENCE OF SEVERAL RATES OF POTASSIUM FERTILIZER ON TUBER AND SOIL CONTENT AND YIELD OF SOLANUM TUBEROSUM Mack A. Wilson* and Michael Aide, Department of Agriculture, Southeast Missouri State University, Cape Girardeau, MO 63701 .

Potatoes (Sol antum tuberosum) were grown on a Lilbourn sandy loam ent isol in Charleston, Missouri, with varying rates of potassium fertilizer. Four rates of murate of potash (KCl) were used; $0,196,392$ and 582 $\mathrm{Kg}-\mathrm{K} / \mathrm{HA}$. Potassium was measured in tuber and soil by atomic absorption spectrophotometry. The amount of soil potassium was apparently high. Although potassium content in the two 'cultivars of potatoes, 'Norchip' and Atlantis' was slightly higher $(2.3-3.7)$ as compared to another researcher's data $(2 \%)$. Obviously, the need for potassium fertilizer for vegetable crops is related to the supplying ability of the soil. Tuber yields ( $\mathrm{Kg} / \mathrm{HA})$ were higher with added rates of potassium fertilizer than the control, and the results were significant. thalds (Kg/HA) of 'Atlantis' were significantly higher than 'Norchip."

MINILEE AND MICKYLEE: HIGH QUALITY ICEBOX WATERMELON CULTIVARS FOR U.S. AND FOREIGN MARKTETS

G. W. Elmstrom* and J.M. Crall, Central Florida Research \& Education Genter, Leesburg, FL 34748 and D. N. Maynard, Gulf Coast Research \& Education Center, Bradenton, FL 34203

Icebox watermelons have been available for some time, but have never attained commercial importance in the United States: In trials at Bradenton, Leesburg, and Live Oak, FL 'Minilee' and 'Mtckylee' (mean weights of 7.5 and 10.0 pounds, respectively) matured earlier than other cultivars and produced yields equal to or better than other icebox cultivars. They had better internal quality and a higher level of resistance to Fusarium wilt than other available icebox cultivars. In storage tests 'Minilee' was less susceptible to chilling injury than 'Mickylee', 'Sugar Baby', or 'Baby Fun'; the flesh of 'Mickylee' and 'Minilee' was firmer and retained firmness better during storage than did the other two icebox cultivars. Icebox melons have appeal to individual home consumers and are well suited for shipment in cartons to both domestic and foreign markets.
NITROGEN AND BORON RATES FOR SELECTED BRASSICA GROWN ON EAST TEXAS ACID, SANDY SOIL

J. V. Davis*, D. R. Earhart, A. T. Leonard, and V. A. Haby, Texas Agricultural Experiment Station, Overton, TX 75684

The potential for east Texas to produce Brassica that could compete favorably with the import market exists. This study was conducted to establish optimum nitrogen and boron rates for 4 Brassica spp. grown on highly leachable east Texas soil, a Bowie series (fine-loamy, siliceous, thermic, Plinthic Paleudult). Broccoli (Brassica oleracea L. Italica, var. Green Comet), cauliflower (Brassica oleracea L. Botrytis var. White Contessa), Chinese cabbage (Brassica rapa L. Pekinensis var. Monument), and Chinese mustard (Brassica rapa $\mathrm{L}$. Chinensis var. What-A-Joy) were ficld grown using 5 rates of $\mathrm{N}\left(0,50,100,150\right.$, and $\left.200 \mathrm{~kg} \cdot \mathrm{ha}^{-1}\right)$ interacted with 3 rates of $\mathrm{B}(0,1.25$

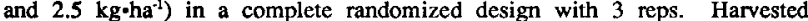
broccoli heads increased average head weight (HW), average head size (HS), and total yield $(Y)$ for each increase of $N$. Cauliflower $H W, H S$, and $Y$ increased up to $150 \mathrm{~kg} \mathrm{~N} \mathrm{ha}^{-1}$. B supplementation did not statistically affect HW, HS, and $Y$ of broccoli or cauliflower. Chinese cabbage $Y$ increased up to $150 \mathrm{~kg} \mathrm{~N} \mathrm{ha}^{-1}$ and produced less $\mathrm{Y}$ at $200 \mathrm{~kg} \mathrm{~N} \mathrm{ha}^{-1}$ than at $50 \mathrm{~kg} \mathrm{~N} \mathrm{ha}^{-1}$. Chinese mustard $\mathrm{Y}$ increased $50 \%$ for the $50\left(\mathrm{~kg}^{-h a^{-1}}\right) \mathrm{N}$ over no added $\mathrm{N}$ with additional $\mathrm{N}$ producing statistically equal $\mathrm{Y}$. $\mathrm{B}$ at $1.25\left(\mathrm{~kg} \cdot \mathrm{ha}^{-1}\right)$ significantly increased cabbage $\mathrm{Y}$, but had no effect on mustard $\mathrm{Y}$.

NUTRIENT REQUIREMENT SCREENING FOR CHINESE CABBAGE IN EAST TEXAS ACID, SANDY SOILS

T Lonard* D $R$ Earhart I $Y$ Dayis, Agricultural Experiment Station, Overton, TX 75684

The increase of the Asian population in Texas has created a demand for specialty vegetables including Chinese cabbage. Chinese cabbage (Brassica rapa L. Pekinensis var. Monument) was grown in a greenhouse to study the main effects of $\mathrm{P}, \mathrm{K}, \mathrm{Ca}, \mathrm{Mg}, \mathrm{S}, \mathrm{Fe}, \mathrm{Mn}, \mathrm{Zn}, \mathrm{B}$, and Mo on plant growth. A randomized complete block design with 4 replications was used. The elements were incorporated and tested at three rates in soil from the Ap horizon of the Darco series (loamy, siliceous, thermic Grossarenic Paleudult). Treatments consisted of a check, where no nutrients were incorporated, all nutrients incorporated at $1 \mathrm{X}$ rates, and all nutrients at $2 \mathrm{X}$ rates. Each nutrient was tested individually at the 0 and $2 X$ rates, while the remaining nutrients were held constant at the $1 X$ rate. Analysis of variance indicated plant growth was affected by applications of $\mathbf{P}, K, S, Z n, B$, and Mo. Regression analysis indicated positive growth responses to $P, K, S$, and $\mathrm{Zn}$, and negative growth responses due to $B$ and $M o$ applications.

EFFECT OF PHOTOPERIOD AND TEMPERATURE REGIMES ON YIELD OF SWEET POTATOES GROWN USING THE NUTRIENT FILM TECHNIOUE (NFT) Desmond Mortley*, Conrad Bons1, Philip Loretan, Walter H111 and Edwin Martinez, George Washíglon Carver Agricultural Experiment Station, Tuskegee University, Tuskegee, AL 36088 Hydroponic experiments using the nutrient $\mathrm{f} \neq \mathrm{lm}$ technique (NFT) were conducted in environmental growth chambers to evaluate the response of two sweet potato cultivars, 'Georgia Jet' and 'TI-155', to two photoperiod and temperature regimes. Vine cuttings of these cultivars were planted in growth channels supplied with modified half-Hoagland nutrient solution using NFT. Plants were subjected to a $24 \mathrm{~h}$ photoperiod or a $12: 12 \mathrm{~h}$ 1ight:dark photoperiod, a constant temperature of $28 \mathrm{C}$ or light:dark temperature of $28 / 22 \mathrm{C}$, P fants were exposed to 1 rradiance levels of $400 \mathrm{umol} \mathrm{m}^{-2} \mathrm{~s}^{-1}$ at canopy leve 1 and $70 \% \mathrm{RH}$. Storage root fresh and dry weights were increased for both cultivars under the $24 \mathrm{~h}$ photoperiod at the $28 \mathrm{C}$ constant temperature. 'Georgia Jet' 'storage root numbers were not affected by any treatment while those for 'TI-155' were reduced under continuous light for both temperature regimes. Follage fresh and dry weights were not affected by any treatment.

TEMPERATURE REGIMES UNDER ROW COVERS IN OVERWINTER ONION TRANSPLANT PRODUCTION

David A. Bender ${ }^{*}$, Texas A\&M Agricultural Research and Extension Center, Lubbock, TX 79401

Two cultivars of onions, 'New Mexico Yellow Grano' and 'Midstar' were seeded in single bed plots in mid-Octoher 1985 and 1987 for overwinter Iransplant production Plots were covered with spunbonded polyester (POL) or tumels of clear polyethylene (CLR) or microperforated polyethylene (PER) (1985 only) in early November and conupared to uncovered controls. Temperatures were monitored $5 \mathrm{~cm}$ above the soil surface under the covers in each plot with three parallel-wired thermocouples. Heal unit (HU) accumulation (number of degrees by which the daily mean temp exceeded $0^{\circ} \mathrm{C}$ ) was recorded for each plot ankl compared with onion plant size. HU accumulation by miclFebruary 1986 under CLR, POL and PER was $139 \%, 131 \%$ and $113 \%$, respectively, of that over bare ground. In mid-March 1988 cumulative HU under CLR and POL were $192 \%$ and $125 \%$ of those over bare ground. Plant diameter varied with variety but increased linearly with cumulative HU for all varieties. 'New Mexico Yellow Grano' reached the ninimum $4 \mathrm{~mm}$ size for transplanting at about $1800 \mathrm{HU}$ while 'Midstar' required only $1500 \mathrm{HU}$. CLR produced useable transplants by early March and the other cuvers by late Marcl. Numbers of useable transplants per meter of bed in mid-March ranged from 3-6 in uncovered plots to 102-153 under PER tunnels, 185-203 under POL and 263-301 under CLR tunnels. CLR Iunnels appear to provide sufficient HU accumulation to produce onion plants for transplanting in carly March in West Texas. 
PRECISION SEEDING FOR PLANTING CABBAGE TO A STAND

R. P. Bracy*, R. L. Parish, P. E. Bergeron, E. B. Moser, and R. J. Constantin, Hammond Research Station, Louisiana Agricultural Experiment Station, Louisiana State University Agricultural Center, Hammond, LA 70403

A study to evaluate the seeding rate necessary for precision seeding cabbage to a stand was initiated during the spring of 1989. A Stanhay precision seeder was used to plant cabbage seed at $10-\mathrm{cm}$ (thinned to $30-\mathrm{cm}$ ), $20-\mathrm{cm}, 30-\mathrm{cm}$ (1 seed/hili), and $30-\mathrm{cm}$ ( 2 seed/hill) spacings. Total weight was not significantly affected by seed spacing, but head size decreased with an increase in number of heads. Cabbage spaced $30 \mathrm{~cm}(1$ seed $/$ hill) apart produced the highest yield of marketable heads (1007 gms). Lab measurements were determined by operating the planter over a lubricated board and measuring seed spacing. Lab measurements of spacing indicated actual spacing was closely associated with expected spacing of each treatment. Field measurements of plant spacing were used to associate seed placement between $1 \mathrm{ab}$ and field sparings. Graphical analys is indicated spacing within a treatment was similar in both lab and field treatments. Small differences between data collected in the lab or field were attributed to loss of plants in the field.

ALTERNATIVE APPROACHES TO SOIL EROSION, FERTILITY, AND PEST MANAGEMENT OF CABBAGE

Warren Roberts" and Bob Cartwright, Wes Watkins Agricultural Research and Extension Center, Oklahoma State University, Box 128, Lane, Oklahoma 74555.

Raised beds ( $0.9 \mathrm{~m}$ wide; $1.8 \mathrm{~m}$ centers, $6.1 \mathrm{~m}$ long) were formed in Oct. 1988. Beds were either left bare or seeded with rye (Secale cereale) or hairy vetch (Vicia villosa). Plots were sprayed with glyphosate in April, 1989. Rye was completely killed, but hairy vetch was not. Bed height was maintained best with beds covered with rye. In a 3 by 4 factorial, four rates of nitrogen $(45,90,134$, and $179 \mathrm{~kg} / \mathrm{ha})$ were applied to each soil cover treatment. On April 17 cabbage (Brassica oleracea $\mathrm{cv}$. Solid Blue 760) was transplanted two rows per bed, with $30 \mathrm{~cm}$ spacing in rows and between rows. There was no mowing or cultivating prior to transplanting. A linear increase in yield was observed with increasing applications of nitrogen. The cabbage yield was less in rye than in vetch or bare soil. The yield difference between rye and bare soil was more pronounced at the low rates of nitrogen than at the high rates of nitrogen. Cabbage grown in rye had significantly fewer aphids, thrips, and cabbage loopers than did cabbage grown in bare soil.

EFFECTS OF NITROGEN SOURCES AND RATES ON CABBAGE YIELDS. J. T. Garrett, Clemson University, Pee Dee Research and Education Center, Florence, SC 29501 Yield and quality responses of 'Market Prize. cabbage to five nitrogen sources and five rates of each source were measured in a replicated test at Clomson and Florence, SC in 1987 and 88 . Soil nitrate solution, analyzed by the ion-electrode method, was monitored bi-weekly with maintenance levels kept throughout the growing season at or above threshold levels of $5,10,15,20$, and $30 \mathrm{ppm}$. The 15-0-14 (nitrate of soda/potash) gave higher total and early yields; higher levels of soluble solids and dry weights when compared to other Nsources of sodium-, ammonium-, potassium-, and calcium nitrate. Uptake, as measured by leaf tissue nitrate ion concentration, increased across soil solution levels up to $20 \mathrm{ppm}$.

PHOSPHORUS RATE AND PLACEMENT METHODS WITH DOUBLE ROW RAISED BEDS

Warren Roberts, Wes Watkins Agricultural Research and Extension Center, Oklahoma State University, Box 128, Lane, Oklahoma 74555 .

Corn planted to originally acidic grassland soils with a low phosphorus (P) content and fertilized at normal rates produced low yields. A factorial study was designed with three application methods (banded, broadcast, tilled) at four rates $\left(34,67,101,134 \mathrm{~kg} / \mathrm{ha}\right.$ ) $\mathrm{P}_{2} \mathrm{O}_{5}$. Sweet corn (Zea mays (L.) was planted in double rows on raised beds $(0.9 \mathrm{~m}$ wide, $1.8 \mathrm{~m}$ centers) with $30 \mathrm{~cm}$ spacing in and between rows. Most yield parameters increased linearly with incrcasing rates of $P$. Banded $P$ produced best yields, but growth was variable between the two double rows per bed. In a second study, $\mathrm{P}_{2} \mathrm{O}_{5}$ ranging from 0 to $403 \mathrm{~kg} / \mathrm{ha}$ was applied by conventional methods. There was a positive response of most yield parameters to increasing rates of $P$. In a third study, soil plugs ( $2 \mathrm{~cm}$ diam., $10 \mathrm{~cm}$ depth) were removed $5 \mathrm{~cm}$ to the side of each plant. Rates of $\mathrm{P}_{2} \mathrm{O}_{5}$ ranging from 0 to $202 \mathrm{~kg} / \mathrm{ha}$ were placed in the plugs. Yield responded positively to increasing rates of $P$. $P$ applied in the plugs produced yield responses similar to $P$ applied conventionally.

IRRIGATION RATE AFFECTS SWEET POTATO YIELD, QUALITY AND STORAGE LIFE

Doyle A. Smittle*, Melvin R. Hall and Paul G. Thompson, Department of Horticulture, University of Georgia Coastal Plain Experiment Station, Tifton, GA 31793 and Department of Horticulture, Mississippi State University, Mississippi State, MS 29762

Responses of sweet potato (Ipomoea batatas (L>) Lam) to irrigation rates were evaluated under line-source irrigation systems on Tifton loamy sand soil in Georgia and on a Bude silt loam soil in Mississippi. Total water (rainfall plus irrigation) rates ranged from about $55 \%$ to $160 \%$ of pan evaporation (Epan). Marketable yields increased with irrigation rate until total water was about $75 \%$ of Epan then dccrcased rapidly with greater irrigation rates. Sweet potato yields were more sensitive to excessive water rates when grown on a silt loam than on a sandy loam soil. Storage loss and quality of cooked 'Jewel' sweet potato roots also increased as the irrigation rate increased until total water was $75 \%$ to $95 \%$ of Epan then decreased rapidly at water rates of 135 to $160 \%$ of Epan.

YIELD AND QUALITY OF TRIPLOID WATERMELON HYBRIDS .

Donald N. Maynard* and Gary W. Elmstrom, Gulf Coast Research \& Education Center, Bradenton, FL 34203 and Gentral Florida Research \& Education Center, Leesburg, FL 34748

Evaluations of 30 triploid (seedless) watermelon hybrids were conducted in the Spring 1989 season at Bradenton and Leesburg, Florida. There was considerable variation in relative cultivar yields at the two locations. However, consistency in some cultivars did occur. 'HMX 7924' produced the highest total yield and 'CFREC 88-2' had high total yields at both locations. On the other hand, 'ACX 882322', 'Fengshan No. 1', 'FMX 28', 'Fummy', 'Honeyheart', 'Nova', and 'NVH 4295' produced low total yields at both locations. Average fruit welght was high for 'Ssuper Sweet Brand 5244', 'CFREC 88-4', and 'HMX 7924' whereas 'ACX 882322', 'FMX 28', 'Fengshan No. 1'. 'Nova', and 'PSR 49087' produced low average fruit weight. Soluble solids exceeded $11 \%$ in all entries at Bradenton whereas two entries were lower than $10 \%$ at Leesburg. Several experimental lines out performed the named cultivars suggesting that future introductions will be superior to those already available.

RESPONSE OF OKRA TRANSPLANTS GROWN UNDER VISPore ROW COVER AND PLASTIC MULCH

V.A.Khan*, C. Stevens Dept. Agri. Sci. Tuskegee

University, Tuskegee, AL 36088 and J. E. Brown

Dept. Hort. Auburn University, AL 36849 Early okra production was evaluated using

'Clemson Spineless' transplants grown under clear polyethylene mulch plus Vispore row cover (VCM), black polyethylene mulch plus VisPore row cover (VBM), clear polyethylene mulch (CM), black polyethylene mulch (BM) and bare soil (BS) for two years. Early yield (1st four harvests in early June) was significantly greater for VCM treatment while total marketable yield at the end of 8 wks were significantly greater for VCM, BM, and VBM treatments, respectively in borh years. Enterprise budget analysis showed that VCM and BM treatments had the highest net-return to management on a per acre basis. 
EVALUATION AND PRODUCTION OF IRISH POTATO IN GEORGIA H.L. Bhardwa $j^{\star}, A . S$. Bhaqsari, and K.G. Haynes, Agricultural Research Station, Fort Valley State College and USDA-ARS, Fort Valley, GA 31030

Two experiments, each with 100 (Solanum tuberosum $I_{\text {.) }}$ genotypes, were planted to compare fall-planted (August 22, 1988) crop with spring-planted (March 14, 1989) crop and to identify high yielding genotypes for each planting. identify high yielding genotypes for each planting. - planting, was observed in both experiments. The mean yield of spring planting $(25.8 \mathrm{Mg} / \mathrm{ha}$ with a range of 9.8 to 49.5 $\mathrm{Mg} / \mathrm{ha}$ ) was significantly higher than mean yield of tallplanting $(18.2 \mathrm{Mg} / \mathrm{ha}$ with a range of 8.5 to $30.2 \mathrm{Mg} / \mathrm{ha})$ The five highest yielding genotypes in fall planting were: B-0245-15, B-0175-2, B-0242-2, Kennebec, and Norchip whereas the five highest yielding genotypes in spring planting were: B-0180-36, B-9792-88, B-0179-17, B9988-7, and Belchip. An additional split-split-plot experiment with 4 replications was initiated March 14, 1989 to identify optimum rate of $\mathrm{N}$ fertilizer and spacing within rows. This experiment consisted of three Nitrogen levels $(0,125$, and $250 \mathrm{~kg} / \mathrm{ha}$ ) three genotypes (At lantic, Kennebec, and La Rouge), and two spacings between plants (10 and $20 \mathrm{~cm}$ ). All Rouge), and two spacings between plants (10 and $20 \mathrm{~cm}$ ). All
plots received $120 \mathrm{~kg} \mathrm{P}$ and $170 \mathrm{~kg} \mathrm{~K} / \mathrm{ha}$. Data showed that $\mathrm{N}$ rates of $125 \mathrm{Kg} / \mathrm{ha}$ and $250 \mathrm{~kg} / \mathrm{ha}$ gave identical tuber yields (50 $\mathrm{Mg} / \mathrm{ha})$. Closer spacing of $10 \mathrm{~cm}$ within rows resulted in significantly higher tuber yield $(46 \mathrm{Mg} / \mathrm{ha})$ as compared to $20 \mathrm{~cm}$ spacing $(33 \mathrm{Mg} / \mathrm{ha})$.

\section{Posters}

EVALUATION OF COWPEA RATOONING POTENTIAL

Douglas C. Scheuring* and J. Creighton Miller. Jr.

Department of Horticultural Sciences, Texas A\&M University, College Station, TX 77843-2133,

David W. Walker,-Department of Horticulture, Louisiana State University, Baton Rouge, LA 70803-2120

Two cowpea cultivars, Pinkeye Purple Hull and Royal Blackeye, were evaluated for their ability to produce a ratoon crop. Dry weight and pod yield were measured following harvest from two different cutting heights (second and fourth node), and stages of pod maturity (green and dry). The cultivar Royal Blackeye produced more green manure or returned biomass following ratooning than did Pinkeye Purple Hull. Cutting height and sampling at different pod maturities influenced ratooning potential. These results suggest that cowpea ratooning appears to be economically feasible and that further screening of cowpea cultivars for ratooning ability is warranted.

A "WATER-DRIP" CONTAINER FOR PREOOOLING, SHIPPING, AND STORING FRUITS AND VEGETABLES

Charles Magee, Johnny Carter, and Clarence Johnson Jr, * Agricultural Research Station, Fort Valley State College, Fort Valley, Georgia 31030

During the summer of 1988 , a study was conducted to determine the effect of an inexpensive reusable styrofoam container on the percent weight loss in collards (bunch and head) after 30 days in a walk-in cooler. This container was designed and constructed for precooling, shipping, and storing fruits and vegetables. The insulated container was provided with a lid-mounted ice cavity that was removable and could be replaced through an access door without removing the lid. The ice cavity melted and was dispersed throughout the container onto the collards. The three treatments used in this study were (1) no top (2) top without ice, and (3) top with ice. Results indicated that both the bunches and heads responded similarly to treatments. The top with ice treatment significantly reduced percent weight loss when compared to the other treatments (top no ice and no top).

FEASIBILITY OF ONCE-OVER MECHANICAL HARVEST OF SUMER SQUASH Jim E. Wyatt* and James A. Mullins, Department of Plant and Soll Science and Department of Agricultural Engineering, University of Ternessee, 605 Airways Blvd. Jackson, TN 38301, and Charles A. Mullins, Department of Plant and Soil science, University of Tennessee, Route 9, Box 363, Crossville, TN 38555

Several spacing, cultivar, ethephon and harvest sequence studies were made on summer squash in 1989 evaluating cultural practices which maximized marketable once-over yield of fruit for processing. Optimum spacing was $30 \mathrm{~cm}$ within rows and $45 \mathrm{~cm}$ between rows. The zucchini and yellow hybrids producing the highest marketable yield were 'Classic' and 'Gold slice', respectively. Ethephon applied at $0.77 \mathrm{~kg} / \mathrm{ha}$ resulted in higher yield than no ethephon. Harvesting two times followed by a seven day delay before a once-over destructive harvest produced a marketable yield equal to three harvests/week for three weeks. A prototype mechanical harvester has been used successfully on yellow hybrids: zucchini hybrids require more force for successful fruit separation.

DIFFERENTIAL RESPONSE OF SEVERAL ROW COVERS ON YIELD OF WHITE POTATOES IN MISSOURI

Mack A. Wilson* and Michael Aide, Department of Agriculture, Southeast Missouri State University, Cape Girardeau, MO 63701 .

Four types of row covers were evaluated on

'Norchip' and. 'Atlant is' potatoes at Charleston,

Missouri on a Lilbourn sandy loam ent isol. Row covers used were spun-bonded polyester, insolar slitted,-clear slitted and Vispore. The row covers increased the mean afternoon soil temperature above the ambient afternoon air temperature from 3 to $25 \mathrm{~F}$ when potato plants were covered. The number of plants which emerged were

significantly different among treatment for the cultivar

'Norchip'. Data for plant height was significantly different between the bare soil control and the row cover treatments. Yield $(\mathrm{Kg} / \mathrm{HA})$ were higher with the spunbonded polyester and insolar slitted row covers for both number and weight of grade A (47.6-82.6 $\mathrm{mim})$

potatoes, and results were significantly different.

SINGLE ROOT SELECTION FOR INTERNAL COLOR OF SWEETPOTATO Melvin R. Hall, Department of Horticulture, University of Georgia Coastal Plain Experiment Station, P. O. Box 748, Tifton, Georgia 31793

In $1983-1987$, a Gardner color difference meter standardized to a pink tile $(L=70.5, a=+23.9, b=+9.3)$ and equipped with an aperture of $3.8 \mathrm{~cm}(1983-1986), 1.9 \mathrm{~cm}$ (1987), or 1.0 $\mathrm{cm}$ (1988-1989) was used to measure lightness $(L)$ and intensity (chroma) of 'Georgia Red' sweetpotato [Ipomoea batatas (L.) Lam.] seed roots cut into longitudinal sections. Individual roots were selected with good color when $L<68$ and chroma $\geq 39$ and fair color when $L \geq 72$ and chroma $<35$ (1983-1985), $L<65$ and chroma $>42$ for good color and $L>80$ and chroma $<25$ for fair color (1985), $L \leq 66$ and chroma $>41$ for good color and $L \geq 85$ and chroma $\leq 20$ for fair color (1987). In each year, roots falling between the defined selection values were discarded. In 1988, root sections from a common 1983-ancestor parent root were bulked for plant propagation if $L$ and chroma values were similar. Subsequent measurements of these bulk populations were made in 1989. Measurements by a color difference meter were helpful in making objective judgements in selecting for internal color of sweetpotato. Also, these measurements were helpful in following changes in internal color through several generations of vegetative propagation.

COMPARATIVE ULTRASTRUCTURES OF VITREOUS AND NON-VITREOUS SWEET POTATO (IPOMOEA BATATAS L)LAM. PLANTS GROWN IN VITRO Nenita V. Desamere* and Billy B. Bhodes, Department of Horticulture, Clemson University, Clemson, South Carolina 29634

Vitrification, a physiological disorder characteristic of in vitro grown plants, was observed in single-node cultures of sweet potato in mannitol-enriched medium during their second year of storage. Vitrified or vitreous sweet potato plantlets were watersoaked, translucent or glassy in appearance, with thick, swollen, leaves and stems, stunted shoot growth and poor root growth. These plantlets were not able to regenerate normal plants when transferred into fresh regeneration medium nor were they able to survive outside culture conditions.

Electron microscopy revealed changes in the ultrastructures of vitrified sweet potato plantlets. Vitrified plants had defective stomatal complex, starch grain-filled chloroplasts, disrupted cell wall, big air spaces (lacunae), high frequency of cell membrane separation from the cell wall, nuclear disintegration, and cytoplasmic disorganization. These changes in the internal structures of vitrified plants were reflected in their abnormal morphology and physiology. 
EFFECTS OF TISSUE BORON CONCENTRATIONS ON DRY MATTER ACCUMULATION IN BROCCOLI

John C. Beaulieu and Dyremple B. Marsh*, Cooperative Research, Lincoln University, Jefferson City, MO 65101

A greenhouse experiment was conducted to examine the relationship between tissue $B$ concentration and dry matter accumulation in broccoli. 'Pirate' was grown in fine silica sand and supplied nutrient solutions containing $0.2,0.8$, $1.4,2.0,2.6,3.2,3.8$, and $4.4 \mathrm{mg} \cdot 1$ iter-1 $\mathrm{B}$. Plants were sampled for the 5 th, 10th, and 15th fully expanded mature leaf, and plant material was collected for dry matter measurement and boron analysis at each growth stage. The lowest specific leaf weights for the 5 th, 10th, and 15th leaves were obtained with the $4.4 \mathrm{mg} \cdot$ Iiter $^{-1}$ treatment. At maturity, leaf, petiole stalk, and shoot dry weights were lowest at $4.4 \mathrm{mg} \cdot$ liter $^{-1}$ B. Treatments supplying less than $3.2 \mathrm{mg}$. liter-1 B, resulted in a notable decrease in tissue $B$ concentrations from the 5 th to the 15 th leaf. There was a linear increase in $B$ concentration in all leaf tissue samples as $B$ treatment increased. At maturity, optimum B concentrations of $531.5,73.7,29.8$, and $64.6 \mathrm{mg} \cdot \mathrm{g}^{-1}$ were found for the lamina, petiole, stalk, and head, respectively. These concentrations occurred in plants receiving treatment levels of $2.0-3.8$ $\mathrm{mg} \cdot$ liter $^{-1} \mathrm{~B}$.

Inheritance of Shortened Fruit Maturation Period in Tomato and its Relation to Fruit Size. Joseph. M. Kemble* and Randolph G. Gardner, Department of Horticultural Science, North Carolina State University, Raleigh, NC 27695

Experiments were conducted in 1989 to determine the heritability of shortened fruit maturation (SFM) period in 871213-1, an inbred cherry tomato line (Lycopersicon esculentum var. cerasiforme (Dunal.) A. Gray), and to determine the relationship between this trait and fruit size. In the first study, a cross was made between $871213-1$ and NC 21C-1, an inbred cherry line. NC $21 \mathrm{C}-1$ had a mean maturation period of 40.8 days compared to 32.0 days for 871213-1. A mean maturation period for the $F_{1}$ hybrid of 32.9 days and 32.2 days was found using 871213-1 as the female and male parent, respectively. Analysis of the data from parental, $F_{1}, F_{2}$ and backcross generations yielded estimates of broad-spense and narrow-sense heritabilities for SFM as 0.72 and 0.56 , respectively. Further analysis indicated that genetic control of SFM was quantitative in nature and highly dominant. $\Lambda$ test for epistatic interaction showed significance. In the second study, an $F_{2}$ population from the cross $871213-1$ x NC 309-1, a large-fruited tomato line (Lvcopersicon esculentum Mill.), was evaluated to determine if any correlations existed between fruit size and SFM. Two fruit characteristics, locule number and fruit weight, were used as estimates of fruit size. Correlations between SFM and these two characteristics were +0.28 and +0.61 , respectively. Broad-sense heritability of SFM was estimated as 0.64 .

THE EFFECT OF COVER CROP AND SOIL SOLARIZATION ON TURNIP GREEN YIELD AND NUTRIENT MINERALIZATION D. R. Earhart*, V. A. Haby, A. T. Leonard, and J. V. Davis, Texas Agricultural Experiment Station, Overton, TX 75684

Soil solarization following previous $\mathrm{N}$ application rates of 0,56 , 112, 168 and $224 \mathrm{~kg} \cdot \mathrm{ha}^{-1}$ as ammonium nitrate, and one cover crop of sorghum-sudān (Sorghum bicolor var.) increased yields of tumip foliage (greens) by $3066 \mathrm{~kg} \cdot \mathrm{ha}^{-1}$ over the non-solarized treatment. Greater yield was obtained with $56 \mathrm{~kg}^{-1} \mathrm{a}^{-1}$ less $\mathrm{N}$ with solarization than non-solatization (112 vs $\left.168 \mathrm{~kg} \cdot h a^{-1}\right)$. A blanket $\mathrm{N}$ application of $22 \mathrm{~kg}^{-1} \mathrm{a}^{-1}$ ameliorated the solarization effect on the 2 nd harvest. Solarization had no significant effect on turnip lcaf clement concentration. Linear and quadratic increases in leaf $\mathbf{N}$ occurred as soil $\mathbf{N}$ increased. There was also a linear increase in tissue $\mathrm{K}$ and $\mathrm{Mg}$ due to solarization. No interactive effects were noted. Soil analysis showed salinity (EC) decreased and $\mathrm{Ca}$ increased with solarization. An increase in $\mathrm{N}$ rates decreased $\mathrm{pH}, \mathrm{NO}_{3}$, and $\mathrm{Mg}$, and increased soil salinity and $\mathrm{NH}_{4}$. Solarization had an interactive effect on soil salinity by increasing $\mathrm{EC}$ at $0 \mathrm{~N}$ and decreasing at 56 to $168 \mathrm{~kg} \mathrm{~N} \cdot \mathrm{ha}^{-1}$.

PROTEINS AND OTHER AGENTS IN BLACKSFOT DISEASE RESISTANCE IN ROSES $\frac{\text { J.M. Shermant, K.S. Reddy, S.E. Newman and J.A. Spencer, }}{\text { Mississippi. State University, Mississippi State, MS }}$ 39762

Most modern roses are highly susceptible to the disease blackspot caused by the fungus Diplocarpon rosae. This contrasts to species roses that are resistant to the disease. To gain information on the biochemical factors in this resistance mechanism, we are studying the involvement of proteins. Soluble proteins of modern roses and species roses were extracted and analyzed by SDS-PAGE. When healthy leaves were examined, there were no distinct differences in the protein patterns, indicating that there are no constitutive proteins involved in the discasc resistance mechanism. There were no differences between healthy and infected leaves of resistant genotypes. When detached leaves of some susceptible types were infected with the fungus new proteins seemed to appear in the healthy region surrounding the blackspot lesion. These proteins may be involved in resisting the spread of the pathogen.

The Use of Three IBA Carriers for Semi-Hardwood Cuttings at Three Rooting Medium Temperatures

A.J.Pertuit. Jr. and J.B. Aitken, Department of Horticulture, Clemson University, Clemson, SC 29634-0375

A randomized complete block experiment (factorially arranged) with $\underline{\text { llex }} \mathbf{x}$ attenuata 'Foster II' semi-hardwood cuttings was conducted to test the efficacy on rooting of three IBA carriers (water, talc, and a hydrophilic gel--"Water Grabber"). Three IBA concentrations $(0,4000$ $8000 \mathrm{ppm})$ and three rooting medium temperatures [ambient (13.3 20.6), 18.3, and $23.9^{\circ} \mathrm{C}$ ] also were employed. Cuttings were harvested at 8 and $15 \mathrm{wk}$ after sticking under intermittent mist. Rooting did not vary with talc IBA concentration. The $29.3^{\circ} \mathrm{C}$ rooting medium increased stem $(1.24 \mathrm{~cm}$, basal)/root dry weight $(\mathrm{g})$ during the first 8 wk but not at $15 \mathrm{wk}$. More rooting occurred at 8 wk with $4000 \mathrm{ppm}$ IBA gel treatment than with talc, with reduced rooting at $8000 \mathrm{ppm}$ IBA (gel). Increased rooting $(8,15$ wk) occurred with $4000 \mathrm{ppm} \mathrm{IBA} \mathrm{with}$ water and gel carriers; however, rooting was less (below the $4000 \mathrm{ppm}$ IBA levels) with $8000 \mathrm{ppm}$ IBA. Overall, water and gel treatments performed about the same.

EVALUATION OF MUSCADINE CULTIVARS FOR NORTH LOUISIANA J.T. Payne* and C.E. Johnson, Calhoun Research Station, Louisiana Agricultural Experiment Station, LSU Agricultural Center, Calhoun, LA 71225 Twenty-six muscadine cultigens were evaluated for fruit size, color, soluble solids, and other horticultural characteristics pertaining to fresh market use. Seventeen cultigens were evaluated for 7 years and 9 were evaluated for 2 years. Entries with the largest fruit size were 'Granny Vale', 'GA 33-1-4', 'Sweet Jenny', and 'Black Fry' with fruit weights averaging over 10.5. grams each. 'Summit', 'GA 33-1-4', 'Sweet Jenny', 'Fry', 'Dixieland', and 'GA 9-4-1' were consistently over $17 \%$ soluble solids during the years of this study. The yield per vine was highest on 'Watergate', 'Carlos', 'Summit', 'Higgins', and 'Redgate'. The highest average yleld was $30.0 \mathrm{~kg}$ per vine on 'Watergate'. Recently released cultivars 'Black Fry', 'Black Beauty', and 'Granny Vale' exhibited extremely good characteristics for the fresh market industry.

\section{ABSCISSION PATTERNS FOR FIVE EARLY MATURING PIGEONPEA} GENOTYPES

Lurline Marsh, Cooperative Research, Lincoln University, Jefferson City, Mo 65101

The floral abscission patterns of five early maturing pigeonpea genotypes; ICPL $1461985 \mathrm{HK}$. ICPL 87 Isotation (85K), ICPL 85010 , ICPL 85024 and ICPL 8304 were studied on field grown plants in Missouri. Individual plants were bagged with nylon nets at the beginning of flowering, and the buds, flowers and pods were collected weekly and counted. Abscission began after anthesis and was excessive throughout most of the flowering period. The number of open flowers which abscised was much greater than that of buds or immature pods. The maximum number of weekly abscission of flowers per plant was 470 for ICPL 146 1985HK. Low night temperature below $10^{\circ} \mathrm{C}$ enhanced abscission of buds, flowers and inmature pods in pigeonpea.

INHERITANCE OF VERMILLION FLESH COLOR IN WATERMELON C.E. Johnson*, J.T. Payne, and K.C. Pee, Calhoun Research Station, Louisiana Agricultural Experiment Station, LSU Agricultural Center, Calhoun, LA 71225

Controlled crosses of a vermillion red flesh color cultivar with 4 normal red flesh color cultivars were made. $F_{1}, F_{2}$, and backeross generations were grown in the field and the fruits evaluated for flesh color. All fruits of the $F_{1}$ generation were vermillion. The $F_{2}$ generation segregated to a $9: 7$ ratio of vermillion to normal in all crosses. The probabilities of fit ranged from 0.10 to 0.95 . This ratio is indicative of two dominant genes with complementary effects or double recessive epistasis. Backcrosses to the dominant parent produced almost all vermillion flesh fruit. Backcrosses to the recessive parents did not fit any documented ratios. Further analysis of the BC generations seems to suggest that flesh color is controlled by two dominant genes. 
SUB-OPTIMUM TEMPERATURE GERMINATION OF 15 WATERMELON CULTIVARS K.C. Pee*, C.E. Johnson, E.W. Bush, Calhoun Research Station, and E.A. Drummond, Dean Lee Research Station, Louis1ana Agr1cultural Experiment Station, LSU Agricultural Center, Calhoun, LA 71225

Seed of 15 watermelon cultivars were evaluated for germinating ability at sub-optimum temperatures. Seeds of each cultivar were exposed to $12.8,15.6,18.3,21.1$, and $30.0^{\circ} \mathrm{C}$ for 8 days in a germinator in accordance to standard seed tcsting rules. Radical emergence was evaluated on day 5 and day 8 . None of the cultivars germinated at $12.8^{\circ} \mathrm{C}$ after 8 days exposure. At $15.6^{\circ} \mathrm{C}$, 'Red-N-Sweet' and 'Blackstone' had germinations of 54 and 40 percent respectively on day 5 , and both increased to over 80 percent on day 8 . At $18.3^{\circ} \mathrm{C}$ 'Red-N-Sweet' and 'Blackstone' exhibited at least 90 percent germination after 5 days while the other 14 cultivars ranged from 2.5 to 86 percent. At $21.1^{\circ} \mathrm{C}$ all cultivars except 'Black Diamond' and 'Allsweet' had germinations of 80 percent or higher on day 5. Germination increased to 90 percent or above by day 8 except for 'Black Diamond' at 83 percent. There were no significant differences among cultivars at the $30^{\circ} \mathrm{C}$ optimum germinating temperature with cultivars having 89.5 percent or higher germination.

CALCIUM, MAGNESIUM, AND SODIUM UPTAKE IN RABBITEYE BLUEBERRIES

James M. Splers, USDA, ARS Small Fruit Research Station, Poplarville, MS 39470

In a sand culture study, increasing Na levels increased lcaf concentration of $\mathrm{Na}, \mathrm{Mg}, \mathrm{Ca}, \mathrm{Mn}$; and $\mathrm{Zn}$, and reduced leaf $K$ and plant dry weight. Magnesium fertilization did not affect leaf concentration of $\mathrm{Ca}, \mathrm{K}$, $\mathrm{Mn}, \mathrm{Fe}$, or $\mathrm{Zn}$. High $\mathrm{Ca}$ fertilization increased leaf $\mathrm{Ca}$ At high $\mathrm{Mg}$ levels, Ca fertilization had a synergistic influence on $\mathrm{Mg}$ uptake. $\mathrm{Ca}$ and $\mathrm{Mg}$ fertilization did not independently influence plant vigor, chlorosis symptoms, or dry weight production of leaves and stems. As levels of $\mathrm{Na}$ fertilization increased, plant vigor and leaf production decreased and chlorosis symptoms increased. With low Na fertilization levels, high $\mathrm{Mg}$ fertilization reduced leaf production but with high $\mathrm{Na}$ fertilization, plants receiving high $\mathrm{Mg}$ levels produced twice the weight of leaves as those with low $\mathrm{Mg}$ fertilization. High $\mathrm{Mg}$ fertilization reduced the detrimental effects of high $\mathrm{Na}$ fertilization on plant growth. This effect may be due to the antagonistic influence of $\mathrm{Mg}$ fertilization on $\mathrm{Na}$ uptake at high $\mathrm{Na}$ fertilization levels.

EFFICACY OF PACLOBUTRAZOL UPTAKE THROUGH PECAN LEAVES, YOUNG SHOOTS, AND BARK

Gregory L. Reighard* and Harvey M. Jessup, Department of Hortfculture,_Clemson University, Box 280, Elgin, SC 29045. Paclobutrazol, a triazole growth regulator, effectively regulates pecan vegetative growth when applied as a soil or trunk drench. However, its absorption and subsequent biological activity in leaves and shoot tissue is not well understood. Terminal shoots from scaffolds of 8 -yr-old 'Chickasaw' pecan trees were treated with paclobutrazol after leaf flush in mid-May of 1988 . Treatments included painting a mixture of $10 \mathrm{mg}$ a.1. paclobutrazol and $1 \mathrm{~m} 1$ distilled water onto elther 1-yr-old wood, green wood, or the abaxial leaf surface. Shoot growth measurements and nut counts were taken in October of 1988 and 1989 on the treated shoots and all shoots arising from them. Paclobutrazol significantly increased the number of nuts per shoot in 1988, but did not affect shoot growth. More nuts were found on shoots from the l-yr-old wood and leaf treatments than from the control and green wood treatments. In 1989, shoot growth was significantly less in the 2 former than the 2 latter treatments. These data indicate that paclobutrazol was absorbed through the bark of 1-y.r-old wood and abaxial leaf tissue and subsequently translocated to areas of shoot growth.

NATURAL COOLING OF TALL BEARDED IRIS

Kurt Knoblauch* and A.E. Einert, Department of Horticulture and Forestry, University of Arkansas, Fayetteville, AR 72701

Irls rhizomes were dug and graded by size. One hundred rhizomes, avg. wt. $23.4 \mathrm{~g}$. , were singly potted in 6 inch plastic standard pots. The pots were plunged, to the pot rim, into fresh sawdust, in an open coldframe.

After 4 weeks in the coldframe, and at subsequent two week intervals, pots were brought into a greenhouse for forcing. Half of each group was forced under long day conditions by night break, following a natural daylength. The other half received continuous lighling. Forcing studies were terminated when irises in the field bloomed.

Bloom dates were similar under long days and continuous light treatments. The highest percentage of plants bloomed under long days. Stalk heights at anthesis averaged 12 to 18 in. Stalk height decreased as natural cooling time increased in plants under long days, but not under continuous light. Plants with shorter flower stalks also had shorter foliage.

POTENTIAL OF SOME INTERSPECIFIC HYBRIDS IN BREEDING SOUTHERN HIGHBUSH BLUEBERRY

C. L. Gupton ${ }^{\star}$ and J, M, Spiers, USDA, ARS Small Fruit Research Station, Poplarville, MS 39470 and A. D. Draper, Fruit Laboratory, Beltsville, MD 20705

Eight clones with various Vaccinium species in their background were evaluated to determine their potential for improving fruit characteristics in the southern highbush blueberry. One clone was crossed with each of the others to produce seven sets of progenies which were evaluated with the parent clones. Heritability estimates were computed as the regression of progeny on parental means for each character. The progenies ranged from small to average berry size and welght, were above average for picking scar, and were generally less than average for color, firmness, and flavor. Mean of progenies was not significantly different from the parental mean for any character. Very high $(0.45-0.85)$ heritability estimates were found for each character except berry firmness $(0.22)$. Thesc results suggest that considerable improvement in each character except possibly berry firmness should result from phenotypic recurrent selection in a broad based population involving these parents.

SPECIFIC ION SELECTIVITY OF 'FORMOSA' AZALEA IRRIGATED WITH SALINE WATER SOURCES

E.W. Bush* and J.T. Payne, Calhoun Research Station, Louisiana Agricultural Experiment Station, LSU Agricultural Center, Calhoun, LA 71225

Container-grown 'Formosa' azalea plants were affected by 1rrigation water quality. Sodium ( $200 \mathrm{ppm})$, supplied by $\mathrm{NaHCO}_{3}$ and $\mathrm{NaCl}$, inhibited plant growth and diminished plant quality. Observable symptoms were tip-burn, marginal necrosis, leaf curling, and eventual defoliation. There was a negative relationship between leaf tissue calcium and magneslum and higher rates of sodium from $\mathrm{NaHCO}_{3}$. Leaf tissue $\mathrm{Cl}$ levels were higher in the higher $\mathrm{NaCl}$ treatments. Sodium treatments inhibited root growth. Plants in $\mathrm{NaHCO}_{3}$ treatments accumulated more $\mathrm{Na}$ than did plants in $\mathrm{NaCl}$ treatments. Media pH and sodium levels following 12 months of sodic irrigation far exceeded acceptable levels for producing marketable container-grown 'Formosa' azalea plants.

PERFORMANCE OF ASIAN PEAR SCIONS ON EYRUS CALLERYANA ROOTSTOCK

Hla Aung* and Frank B. Matta, Department of Horticulture, Mississippi State University, Mississippi State, MS 39762 One year old Asian pear scion cultivars were grafted onto Pyrus calleryana rootstock utilizing two grafting methods (whip grafting and splice side grafting). Percentage survival of grafted scions was 78 and 96 via the splice side graft and the whip graft, respectfully. Shoot length and caliper 80 days after grafting did not vary between cultivars. 'Yakumo' and 'Chojuro' produced a greater number of branches as compared to the remaining cultivars. 'Yakumo', 'Chojuro', 'Seuri' and 'Hosui' produced the least amount of shoot growth. Branching angle was greatest for 'Seigyoku', 'Chojuro' and 'Yakumo' with 60 70 , and 55 degrees, respectfully. As indicated by leaf area, 'Seuri' and 'Hosui 'produced large leaves and 'Yakumo' and 'Chojuro' produced small leaves. 
ETHYLENE INDUCED RIPENING OF GREEN MATURE PASSION FRUIT (PASSIFLORA EDULIS, SIMS)

Harvey E. Arjona* and Frank B.Matta, Department of Horticulture, Mississippi State University, Mississippi State, MS 39762

Passion fruit has become a popular addition to our diet and is currently grown in the United States. Passion fruit shelf life could be extended if green mature fruit can be induced to ripen after exposure to ethylene. Greenhouse grown purple passion fruits were harvested in a green mature stage 55 and 60 days after anthesis (DAA) and stored for 10 days at $10^{\circ} \mathrm{C}$. After storage half of the fruits were treated. with $10 \mathrm{ppm}$ ethylene for 35 hours and stored at room temperature $\left(21^{\circ} \mathrm{C}\right)$ for 48 hours. The juice of treated and non-treated fruit was analyzed for comparison with juice of vine-ripened fruit. Total soluble solids and $\mathrm{pH}$ of the juice did not differ in green mature fruits harvested 55 and 60 DAA. compared to vine-ripened fruits (70-80 DAA). Sucrose content decreased and fructose and glucose increased after storage, regardless of thylene treatment. Fruits harvested 55 and $60 \mathrm{DAA}$, with or without ethylene and stored for 10 days, developed the same sugar content, soluble solids and $\mathrm{pH}$ as those that ripened on the vine.

SCREENING SWEET POTATOES FOR DROUGHT TOLERANCE Lavetta Newel1*, Tonda Bardwel1, and James 0. Garner, Jr., Mississippi State University, Mississippi State, MS 39762

In two experiments, 16 sweet potato genotypes (Ipomoea batatas L.) were evaluated fur drought tolerance using the detached - leaf water loss method as reported by walker and Miller (1986). Dry weight loss was also determined. Differences in the rate of leaf water loss over a 48 hour period were found.

Vardaman had the greatest amount of dry matter loss and the lowest level of water loss. However, no relationship between dry matter loss and water loss was found.

ENZYMATIC CHANGES IN REFRTGERATED SHELLED SOUTHERN PEAS Tonda Bardwe11*, James 0 . Garner, Jr., Huang Jin Xing Science and Technology, Mississippi State University, Mississippi State, MS 39762

Fresh shelled southern peas were dipped in solutions of $15 \mathrm{ppm}$ chlorine, $1.0 \% \mathrm{Ca}$, cold $\mathrm{H}_{2} \mathrm{O}$ or a combination of $15 \mathrm{ppm}$ chlorine and $1.0 \% \mathrm{Ca}$. These treatments were compared to a no dip treatment and blanching for $70 \mathrm{sec}$ at $205^{\circ} \mathrm{F}$. Polyphenoloxidase (PPO) activity of pea extracts were determined in 5 day intervals for 20 days Quality evaluations for color changes and texture were also made. PPO activity was the only enzyme that showed an increase in activity with refrigeration time. The blanched peas were lower in quality for a fresh refrigerated product.

DIFFERENCES IN CHILLING TOLERANCE OF SWEET POTATO GENOTYPES Chana Phromtong*, Floyd M. Woods, James O. Garner, Jr., and Juan L. Silya Departments of Horticulture and Food Science and Technology, Mississippi State University, Mississip̈pi State, MS 39762

Sixteen sweet potato (Ipomoea batatas L.) genotypes were chilled for 36 hours at $5 \mathrm{C}$ with $85 \% \mathrm{RH}$ and a 12 hour photoperiod. Transpiration, leaf diffusive resistance and visual scores for plant quality were taken before chilling and 2 days after the chilling treatment. Differences between the before and after readings were used to indicate the extent of chilling injury or tolerance. Visual score gave a better separation of the genotype for tolerance, however, the difference in transpiration was the most critical of the two objective measurements.

THE RELATIONSHIP OF ROOTSTOCK WITH 'STARKSPUR SUPREME' SCIONS TO MATURITY INDICES

Dwight Wolfe* and Gerald Brown, University of Kentucky, Research \& Education Center, P. 0. Box 469, Princeton, KY 42445 The maturity indices of percent fruit drop, percent soluble solids, and flesh firmness of apples from trees with 'Starkspur Supreme' scions on nine rootstocks were compared over the five-year pertod 1985-1989. The nine rootstocks included EMLA 7, EMLA 9, EMLA 26, EMLA 27, Mark, MAC 24, Otcawa
3, OAR 1 , and $M 9$.

The five-year averages of each of the maturity indices varied significantly among the nine stions. The average percent fruit drop was more strongly correlated with trunk crosssectional area $(r=0.572)$ than it was with cumulative yield efficiency $(r=0.346)$. Flesh firmness was significantly correlated with cumulative yield efficiency $(r=0.398)$ but not with efther trunk cross-sectional area or cumulative yield. The average percent soluble solids was more significantly correlated with trunk cross-sectional area $(r=0.770)$ than it was with either cumulative yield efficiency $(r=0.383)$ or cumulative yield $(r=0.637)$. It is suggested that tree size may be used as an indicator for predicting maturity in cases where little or no information is available on the effects of that particular rootstock on maturity.

CRITICAL TISSUE MOISTURE LEVELS NEEDED FOR MAINTENANCE OF ROSE PLANT VIABILITY. $\mathrm{H}$, Brent Pemberton and William $E$. Roberson*, Texas A\&M University Agricultural Research and Extension Center, P. O. Drawer E, Overton, Texas 75684

Field grown 'Mr. Lincoln' rose plants were dug and wrapped in plastic to reduce moisture loss during transport to the lab. Plants were then pruned, weighed, and retumed to the plastic cover. After recording initial weights, plants were allowed to dry for $0,1,4,7$, or 24 hours at $16^{\circ} \mathrm{C}$. Plants were then oven dried, potted, or soaked in water for 20 hours before potting for each drying time treatment. The potted plants were forced to first flower in a glasshouse at which time growth mcasurements were made. Undried plants had a moisture content of $48 \%$. Seven hours drying reduced moisture content to $41 \%$, but had no effect on growth or flowering. The 24 hour drying time resulted in a plant moisture content of $33 \%$, a plant loss of $44 \%$, and delayed growth initiation and flowering by up to 15 days compared to undried controls. Soaking after 24 hours drying increased plant survival from 38 to $75 \%$. Plants that survived the excessive drying produced flowering growth comparable to plants with a moisture content of $>40 \%$. A critical moisture level for rose plant survival was found to be between 33 and $41 \%$.

\section{SEASONAL WOOD DEVELOPMENT EFFECTS ON FROST}

TOLERANCE AND FRUIT MATURITY OF RABBITEYE BLUEBERRIES E. W. Neuendorf* and K. D. Patten, Texas Agricultural Experiment Station, Overton, TX 75684

Rabbiteye blueberry flower buds are initiated and differentiated on three distinct wood types - spring growth on old weak growth, spring growth on vigorous 1-year-old shoots, or postharvest late summer/fall growth. Flower buds on spring growth are usually formed and visible by July, while buds formed on postharvest growth flushes appear in late summer and early fall. To evaluate the influence of wood type on cold damage, shoots of 'Tifolue' and 'Delite' were tagged by season of growth. Following a $-10^{\circ} \mathrm{C}$ freeze in Feb. flower buds on shoots from each growth flush were examined for dead ovaries. Flower buds surviving the freeze were evaluated following a $-2^{\circ}$ late frost in Mar. Influence of wood type on floral bud and fruit development was determined. All fruit were removed from 5 shoots of each wood type on 2 harvest dates corresponding to early and midseason harvests. Floral buds formed on fall growth were more freeze and frost tolerant than those initiated on spring growth at similar stages of bud development. 'Tifblue' was more cold tolerant than 'Delite'. Floral buds formed on both spring wood types were earlier to develop than buds formed on fall wood. There were no differences in ripening patterns and quality of fruit removed from spring - new and fall wood. Fruit formed on spring - old wood were later maturing and smaller sized for both harvests than spring-new or fall wood. Postharvest pruning to encourage fall growth may be a cultural means of frost avoidance.

PLANT METHOD, GROUND COVER AND IRRIGATION LEVEL EFFECTS ON MUSKMELON PKODUC"I'LON

Robert Wiedenfeld*, Eden Hinojosa and Robert Stubblefield, Texas A\&M University Agricultural Research \& Extension Center, 2415 East Highway 83, Weslacu, Texas 78596

A study was conducted in subtropical south Texas in 1989 to determine the effects of planting method, polyethylene mulch, and rate of drip irrigation on cantaloupe growth, yicld and quality. Irrigation at $.25, .50, .75,1.0$, or 1.25 times pan evaporation had little effect on soil moisture or yield, with a11 water application levels keeping the soil close to field capacity. Transplanting vs. direct seeding enhanced early vine growth and caused earlier yield, although direct seeded plants later caught up and had final cumulative yields slightly higher than the transplants. Black polyethylene mulch also improved earliness and reduced the number of culls compared to bare soll, but at the lowest watering level total yields were reduced by the mulch due to deflection of the rainfall received. The combined practices of transplanting and polyethylene mulch caused approximately a 9 day earliness advantage over the treatment that was direct seeded on bare soil although final yield was unaffected. Soil salinity buildup may cause problems which would affect the position of the drip line and the frequency and amount of water applied. 
FOLIAR NITROGEN EFFECTS ON UNION PROUUCTION AND DAMAGE BY THRIPS AND PURPLE BLOTCH

Robert Wiedenfel.d*, B. Scully, Marvin Miller, Jonathan Edelson, and Jiandong Wang, Texas A\&M University Agricultural Research and Extension Center, 2415 East Highway 83, Wes 7 aco, TX 78596

Purple blotch (Alternaria porri) and thrips (Thrips tabaci) can seriously reduce yields of short day onions in South Texas. The level of injury caused by these organ isms is influenced by the concentration of nitrogen in leaf tissue. Lower levels of tissue nitrogen increase susceptibility to A. porri but decrease susceptibility to thrips. The purpose of this study was to evaluate the effect of tissue $N$ levels on joint susceptibility of 4 onion cultivars to $A$. porri and thrips. Fol iage was fertilized at $0,4,8, \overline{12}$ or 16 lbs $\mathrm{N} / \mathrm{ac} / \mathrm{wk}$ for 6 weeks. Nitrogen concentrations in onion leaves varied over $t$ ime and by leaf age, but showed very little effect due to foliar fertilization. Significant differences in thrips were noted among cultivars, but not among leaf $\mathrm{N}$ concentrations with cultivars. Purple blotch outbreak occurred late in the growing season and was not related to léaf $N$ levels. Total $N$ uptake failed to respond to foliar fertilization, therefore overall use efficiency of the foliar $\mathrm{N}$ applied averaged only about $10 \%$ relative to the amount taken up in the check plots.

THE INFLUENCE OF SUPRAOPTIMAL ROOT-ZONE TEMPERATURES ON ${ }^{14} \mathrm{C}$ PHOTOSYNTHATE PARTITIONING IN ILEX CRENATA THUNB. 'ROTUNDIFOLIA' John M. Ruter and Dewavne L. Ingram, Department of Ornamental Horticulture, IFAS, University of Florida, Gainesville, FL 32611

Ulex crenata Thunb. 'Rotundifolia' split-root plants were grown for 3 weeks at root-zone temperatures of 30/30,30/34,30/38,30/42,34/34, 38/38 and 42/42. The $38 \mathrm{C}$ root-zone temperature treatment was the upper threshold for a number of growth and physiological parameters. A portion of the root system grown at near optimum temperatures could compensate in terms of shoot growth for part of the root system exposed to supraoptimal root-zone temperatures up to the $38 \mathrm{C}$ critical threshold. Higher root-zone temperatures did not affect photosynthetic rates or root:shoot ratios, but attered photosynthate partitioning to different stem and root sinks. Although no differences were found for total ${ }^{14} \mathrm{C}$ partitioned to the roots, partitioning of the ${ }^{14} \mathrm{C}$ into soluble and insoluble fractions and the magnitude of root respiration and exudation were influenced by treatment. Heating half of a root system at $38 \mathrm{C}$ increased the amount of ${ }^{14} \mathrm{C}$ respired from the heated side and increased the total $\mathrm{CO}_{2}$ respired from the non-heated $(30 \mathrm{C})$ half. Exposure of both roo halves to $42 \mathrm{C}$ resulted in membrane damage which increased the leakage of ${ }^{14} \mathrm{C}$ photosynthates into the medium.

\section{Anderson Graduate Student}

EFFECT OF CONTINUOUS VS PERIODIC $\mathrm{PH}$ ADJUSTMENT ON GROWTH OF 'GEORGIA JET' AND 'TI-155' SWEET POTATO CULTIVARS GROWN USING THE NUTRIENT FILM TECHNIQUE (NFT)

Edwin Martinez*, Conrad Bonsi, Philip Loretan, Walter Hill, Desmond Mortley and Carlton Morris, George Washington Carver Agricultural Experiment Station, Tuskegee University, Tuskegee, AL 36088

Sweet potato-, selected as a potential food source for future long-term manned space missions, is being evaluated for NASA's Controlled Ecological Life Support Systems (CELSS) program. Greenhouse experiments were conducted to determine the effects of two $\mathrm{pH}$ treatments on the growth and storage root yield of 'TI-155' and 'Georgia Jet' sweet potato cult1vars. Vine cuttings of these cultivars were grown in a specially designed Tuskegee University NFT system. Plants were subjected to a continuous $\mathrm{pH}$ treatment in which the nutrient Bolution $\mathrm{pH}$ was maintalned at $5.00+0.10$ chroughout the growth period, and a periodic $\mathrm{pH}$ treatment in which the nutrient solution $\mathrm{pH}$ was adjusted to 6.00 at biweekly changeover Intervals and when reservoirs were refilled with delonized water between b1weekly changeovers. Results showed that for both cultivars the treatment with periodic $\mathrm{pH}$ adjustment had olgniflcantiy higher storage root yleld than treatment with continuous $\mathrm{pH}$ adjustment. This experiment is being repeated.

PRETRANSPLANT NUTRITIONAL CONDITIONING (PNC) INFLUENCE ON EARLINESS AND YIELD OF TOMATO Regina Melton* and Robert Dufault, Horticulture Department, Clemson University, Clemson, SC 29632

'Sunny' tomato seedlings were nutritionally conditioned in 1988 with solutions containing $N$ at 100,200 and $300 \mathrm{ppm}, P$ at 10,40 and $70 \mathrm{ppm}$ and $K$ at 100 ppm, and in 1989 with $N$ at 50,100 and 200 ppm, $P$ at 10 and
$40 \mathrm{ppm}$, and $\mathrm{K}$ at $100 \mathrm{ppm}$. The seedlings were cold stressed at $2 \mathrm{C}$ for 8 consecutive nights prior to field planting to simulate possible spring field conditions. The objective was to determine the effect of PNC and cold stress on earliness to flower and fruit and yield. In 1988, earliness to flower and fruit set increased with $\mathrm{N}$ rate, increasing from 100 to $200 \mathrm{ppm}$ and in 1989 from 50 to $200 \mathrm{ppm}$; and in both years with $\mathrm{P}$ increasing from 10 to $40 \mathrm{ppm}$. Early yield was not affected in 1988 by $N$ or $P$, but in 1989 early yield was higher with N PNC at 100 to $200 \mathrm{ppm}$. Total marketable yield increased in 1988 from plants conditioned with $\mathrm{N}$ from 100 to $200 \mathrm{ppm}$ and in 1989 from 50 to $100 \mathrm{ppm}$. P increasing from 10 to $40 \mathrm{ppm}$ also increased total marketable yield, but only in 1988 . Cold stress had no effect on the variables reported. A PNC regime of $200 \mathrm{ppm} \dot{\mathrm{N}}$ and $40 \mathrm{ppm} \mathrm{P}$ is suggested to condition seedlings to produce earlier and higher yields.

DNA FINGERPRINTING OF ROSES FOR PATENT PROTECTION Mark Hubbard*, John Kelly, Albert Abbott and Robert Ballard, Départment of Horticulture and Department of Biological Sciences, Clemson University, Clemson, SC 29634-0375 To protect plant patents, rose breeders would benefit from a reliable and sensitive method for differentiating cultivars at the genetic level. Rcombinant DNA technologies are being employed to characterize individual DNA structure of numerous rose cultivars. Restriction fragment length polymorphisms (RFLPs) are being studied to develop a characteristic pattern, or fingerprint for each cultivar. DNA from various cultivars is restriction enzyme digested and the fragments separated by agarose gel electrophoresis. The gel is Southern blotted and hybridized with probes from the rose DNA library to yield RFLPs. RFLPs are being located and will eventually result in a characteristic fingerprint for each cultivar.

END-OF-DAY FAR-RED LTGHT PROMOTES POSTHARVEST LEAF CHLOROSIS IN POTTED MINTATURE ROSES

David G.Clack* and John W. Kelly, Department of horticulture, Clemson University, Clemson, SC 29634

potted miniature roses (Rosa $x$ hybrida 'Confection' \& 'Meijikatar') were treated at the end of each 8 hour photoperiod with $30, \mathrm{~min}$ of red (R) or far-red (ER) light for 21 days. These light treatments convert phytochrome to the Pfr and Pr forms respectively. Plants were paper sleeved and stored in cardboard boxes at $160 \mathrm{C}$ for 5 days to simulate postharvest shipping conditions.

'Meijikatar' plants treated with FR light showed more postharvest leaf chlorosis than plants treated with $R$ light or controls.

'Meijikatar' plants treated at the end of each 12 hour photoperiod with FR light exhibited more postharvest leaf chlorosis than plants treated with $R$ light. There were no differences in postharvest leaf chlorosis between plants treated with FR light followed by $R$ light or plants treated with $R$ light followed by $F R$ light. These results suggest that an avoidance of end-of-day FR light will result in less postharvest leaf chlorosis in potted roses.

\section{J. B. Edmond Undergraduate}

DIFFERENTIAL TOLERANCE OF VELVETLEAF (ABUTILON THEOPHRASTI), JIMSONGEED (DATURA STRAMONIUM), AND MORNINGGLORY (IPOMEA HEDERACEA) TO CLOMAZONE

Carla D. White* and L. Weston, Ph.D., College of Agriculture, University of Kentucky, Lexington, KY 40526

The purpose of this experiment was to determinc if differential tolerance levels of velvetleaf (Abutilon theophrast $i$ ), jimsonweed (Datura stramonium) and morningglory (Ipomea hederacea) to $14 \mathrm{C}$ clomazone, a preemergence herbicide, was due to uptake, translocation and metabolism of clomazone. The plant species were placed in a clomazone Hoagland solution for 48 and 96 hours. Afterwards, extraction of chlorophyll, oxidation of plant material, and liquid scintillation spectroscopy procedures were used to determine if the differences existed. Morningglory were found to have a higher rate of metabolism and was the most tolerant to clomazone. It is hypothesized that these results are due to Morningglory's larger size and tendency to retain clomazone in the roots. 
PRODUCTION OF SATIN FLOWER POTTED PLANTS FROM CUTTINGS Gwendolyn Hartley* and Robert G. Anderson, Department of Horticulture and Landscape Architecture, University of Kentucky, Lexington, KY 40546

Satin flower (Clarkia amoena subsp. whitneyi; syn. Godetia whitneyi) is a coo temperature, high light plant used as a cutflower in Japan, Europe and California The stiking flower color patterns, large, long-lasting flowers and branching pattern could make this plant an important potted flowering plant. Cuttings, $6-8 \mathrm{~cm}$ long with flower buds $(0.5-2.0 \mathrm{~cm}$ long), were harvested from secondary and tertian stems of field-grown pinched plants of 'Grace Red'. Cuttings were rooted in intermittent mist and potted in $10 \mathrm{~cm}$ pots two weeks later. The terminal flower buds and stem tip were removed one week later and the plants flowered within 4 weeks with 4-6 equal lateral branches. In the fall, 'Grace Rose Pink' seed was sown Oct. 4, 1989, plants were grown under 100 umole $\mathrm{s}^{-1} \mathrm{~cm}^{-2}$ HPS $18 \mathrm{hr}$ supplemental light. Cuttings from the primary stem were harvested at the same stage, rooted in two weeks, potted and pinched one week later. Cuttings grown under supplemental light flowered 4 weeks later while cuttings grown under ambient light flowered over 10 weeks later. Over $70 \%$ of the terminal cuttings in supplemental light were $22-30 \mathrm{~cm}$ tall with 4-6 equal lateral branches that flowered uniformly

SUPPLEMENTAL APPLICATION OF CALCIUM INFLUENCES UNICONAZOLE ACTIVITY ON V-14 GUTBIER POINSETTIAS

D.K. Harrist, A.D. Owings, and S.E. Newman, Department of Horticulture; Missis

sissippi State, MS 39762.

Uniconazole has been demonstrated to not on $1 y$ reduce plant height, but suppress the development of xylem and phloem in stem tissue. Supplemental calcium nutrition in poinsettias has been demonstrated to reduce marginal bract necrosis, reduce leaf puckering and increase stem strength. Studies were conducted to determine the influence, of uniconazole on Gutbier $v-14$ Glory poinsettias grown with supplemental calcium applied either as a foliar spray or a media drench.

Supplemental calcium applications improved the growth habit of uniconazole treated poinsettia plants. Bract coloration was intensified by foliar applications of calcium and uniconazole.
EARLY TEMPERATURES INFLUENCE BROCCOLI GROWTH AND HEAD QUALITY A. R. Jones* and D. C. Sanders, Dept. of Horticultural Science, North Carolina State University, Raleigh, NC 27695-7609

R. J. Dufault, Dept. of Horticulture, Clemson University, Clemson, SC 29407

Three broccoli (Brassica oleracea L. Italica group)

cultivars (Baccus, Packman, and Southern Comet) were grown for 14,24 , or 34 days at $22 / 18 \mathrm{C}$ (day/night) in a greenhouse.

Then plants were moved to growth chambers where temperatures were maintained at $26 / 22,30 / 26$, or $34 / 30 \mathrm{c}$ and were grown for 1,2 , or 3 weeks before returning them to the greenhouse. A1l varieties when exposed to high temperatures developed smaller heads. Packman when exposed to high temperatures resulted in a reduction in uniformity. Other cultivars were not effected. Lack of openness, an important marketable characteristic was reduced by high temperatures. However, Baccus at 34 days old was not effected by the heat. We would expect this response since this is the head development stage and cultivar is heat tolerant. Plant exposed to high temperatures developed heads earlier when held for 3 weeks. When plants were held at $36 / 30 \mathrm{C}$ for 3 weeks, the largest reduction in plant growth was recorded. However, all plants showed a reduction in growth when exposed to high temperatures. 